\title{
Threatened gastropods under the evolutionary genetic species concept: redescription and new species of the genus Aylacostoma (Gastropoda: Thiaridae) from High Paraná River (Argentina-Paraguay)
}

\author{
ROBERTO E. VOGLER ${ }^{1,2 *}$, ARIEL A. BELTRAMINO ${ }^{3,4}$, JUANA G. PESO $^{1}$ and \\ ALEJANDRA RUMI ${ }^{2,4}$ \\ ${ }^{1}$ Departamento de Biología, Facultad de Ciencias Exactas, Químicas y Naturales, Universidad \\ Nacional de Misiones, Rivadavia 2370, N3300LDX Posadas, Argentina \\ ${ }^{2}$ National Science Agencies, Consejo Nacional de Investigaciones Científicas y Técnicas \\ (CONICET), Argentina \\ ${ }^{3}$ National Science Agencies, Agencia Nacional de Promoción Científica y Tecnológica \\ (ANPCyT), Argentina \\ ${ }^{4}$ División Zoología Invertebrados, Facultad de Ciencias Naturales y Museo, Universidad Nacional \\ de La Plata, Paseo del Bosque s/n, B1900FWA La Plata, Argentina
}

Received 4 December 2013; revised 29 April 2014; accepted for publication 4 June 2014

\begin{abstract}
The genus Aylacostoma Spix, 1827, is mainly endemic to South America, and comprises about 30 nominal species, most of which were described based solely on conchological features following the typological approaches of most of the $19^{\text {th }}$ and the mid-20 $0^{\text {th }}$ century authors. Here, we redescribe Aylacostoma chloroticum Hylton Scott, 1954, and describe Aylacostoma brunneum sp. nov. from the High Paraná River (Argentina-Paraguay) by means of morphological and molecular characters. Both are threatened species currently included into an ongoing ex situ conservation programme, as their habitats have disappeared because of damming and the filling up of the Yacyretá Reservoir in the early 1990s. We used DNA sequences from cytochrome b and cytochrome oxidase subunit I (COI) genes to estimate their genetic distances, and the COI sequences were also used to assess their specific status under the evolutionary genetic species concept by means of the $K / \theta$ method. Our results clearly demonstrate that both must be recognized as evolutionary genetic species, despite only minor differences in morphological characters other than in the shells.
\end{abstract}

(C) 2014 The Linnean Society of London, Zoological Journal of the Linnean Society, 2014, 172, 501-520. doi: $10.1111 /$ zoj.12179

ADDITIONAL KEYWORDS: anatomy - asexually reproducing taxa - endangered freshwater snails - ex situ conservation programme - mitochondrial DNA.

\section{INTRODUCTION}

Thiaridae Gill, 1871, is a family of gastropods that includes species that have been intensely studied because of their reproductive and life history strategies, and their capacity for successful colonization of new habitats worldwide (Strong et al., 2011). Although

*Corresponding author. E-mail: robertovogler@fceqyn.unam. edu.ar; robertovogler@yahoo.com.ar understanding of Thiaridae has increased in recent times (e.g. Glaubrecht, 1996, 1999, 2006; Gomez, Strong \& Glaubrecht, 2011; Strong et al., 2011), little is known about almost all South American representatives, most of which were described based solely on conchological features following the typological approaches of most of the $19^{\text {th }}$ and mid-20 $0^{\text {th }}$ century authors (e.g. Reeve, 1860; Ihering, 1902, 1909).

Several genus-group names are available for Neotropical thiarids: e.g. Aylacostoma Spix, 1827, Hemisinus Swainson, 1840, Verena H. \& A. Adams, 1854, 
Longiverena Pilsbry \& Olsson, 1935, and Basistoma Lea, 1852 (Morrison, 1954; Gomez et al., 2011). The limits amongst these taxa remain to be established; however, comparative analyses amongst them are still difficult given that the available data are very scarce and highly dispersed. An attempt to organize Neotropical thiarids was made by Morrison (1954), which included the genus Aylacostoma Spix, 1827, within the Thiaridae, a view that has not been changed since then; despite the fact that the concept of Thiaridae has changed radically since Morrison (Strong et al., 2011 and references therein). However, the genus has never been comprehensively revised, and most of our knowledge rests on the original species descriptions. At the beginning of this century, the anatomy of three Brazilian species of Aylacostoma was described by Simone (2001), thus providing new data for comparison.

In Argentina and Paraguay, the occurrence of species of Aylacostoma was first reported by Hylton Scott (1953, 1954). She described Aylacostoma guaraniticum (Hylton Scott, 1953), Aylacostoma chloroticum Hylton Scott, 1954, and Aylacostoma stigmaticum Hylton Scott, 1954; which are considered to be viviparous and parthenogenetic (Quintana \& Mercado Laczkó, 1997; Ostrowski de Núñez \& Quintana, 2008). The three species were recorded in highly oxygenated freshwater habitats near the Yacyretá-Apipé rapids in the High Paraná River at the border area between Argentina and Paraguay (Vogler, 2012; Peso, Molina \& Costigliolo Rojas, 2013a; Peso, Costigliolo Rojas \& Molina, 2013b). However, these habitats have disappeared because of damming and the filling up of the Yacyretá Reservoir in the early 1990s (Quintana \& Mercado Laczkó, 1997; Meichtry de Zaburlín et al., 2010). Owing to this flooding, the three species, which are endemic to the area and are strictly confined to the rapids, have been threatened with extinction (Vogler, 2013). Aylacostoma guaraniticum and A. stigmaticum are listed by the International Union for Conservation of Nature (IUCN) as 'Extinct in the Wild' (Mansur, 2000a, b), but presently could be categorized as extinct as no specimens of these species have been reported to have survived in nature or captivity (Peso et al., 2013a, b). It is important to mention that an ongoing ex situ conservation programme was developed in the 1990s. This programme, known as the 'Aylacostoma Project', is being conducted by the Universidad Nacional de Misiones (Posadas, Argentina) jointly with the Museo Argentino de Ciencias Naturales (Buenos Aires, Argentina), and is supported by the Entidad Binacional Yacyretá (EBY, ArgentinaParaguay). Currently, only A. chloroticum and a recently recorded new morphotype are included in the programme (Vogler, 2013).

In the present study, we provide the taxonomic description of the two threatened species of Aylacostoma included in the ex situ conservation programme men- tioned above (A. chloroticum has been redescribed, the new morphotype has been described as a new species) as a contribution towards future comparative studies of this poorly known genus. As both are fully asexually reproducing taxa, they have been described under the evolutionary genetic species concept (EGSC) and the description includes conchological and anatomical data.

\section{MATERIAL AND METHODS}

The study was based on the examination of specimens housed in malacological collections at the Museo de La Plata (MLP; La Plata, Argentina) and Museo Argentino de Ciencias Naturales (MACN; Buenos Aires, Argentina). Additional specimens that were collected in the High Paraná River between 1994 and 2012 came from the ongoing ex situ conservation programme taking place at the Universidad Nacional de Misiones (UNaM; Posadas, Argentina). Living specimens were relaxed in $0.1 \%$ Nembutal solution for 8-10 h, subsequently immersed in hot water $\left(60-70{ }^{\circ} \mathrm{C}\right)$, and finally fixed in Railliet-Henry's fluid (5\% formalin, $2 \%$ acetic acid, and $0.6 \%$ aqueous sodium chloride). Vouchers of muscle tissue were obtained and preserved in $96 \%$ ethanol for molecular analyses. Seven shell measurements were taken (Fig. 1): total length (TL), penultimate whorl length

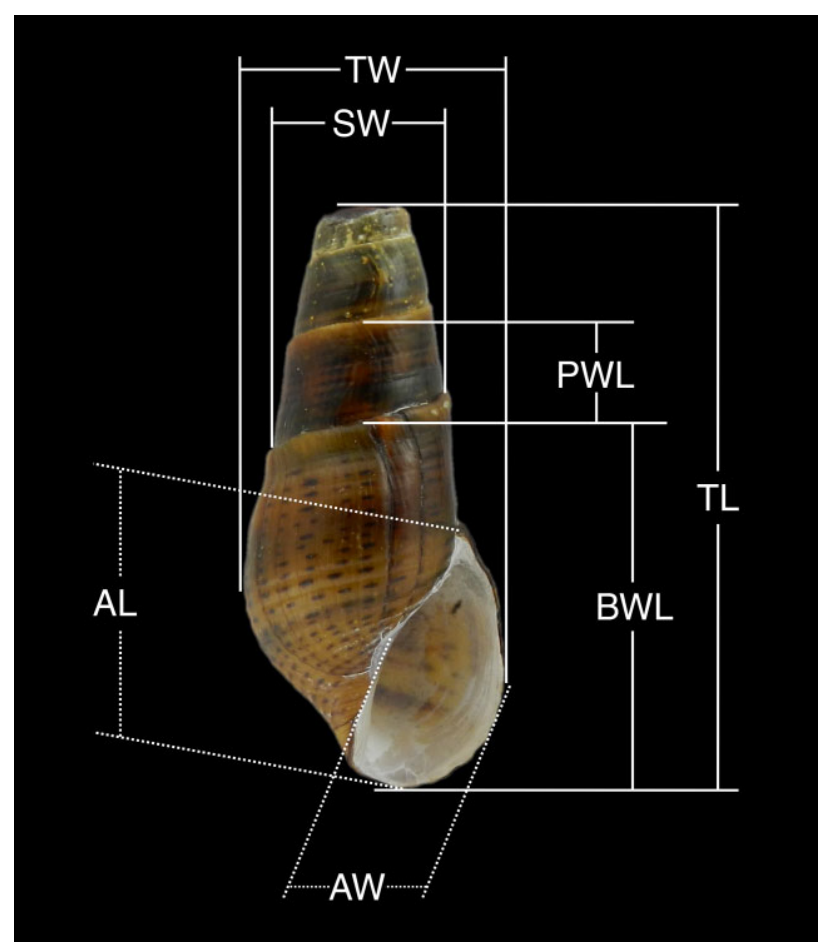

Figure 1. Shell measurements used for Aylacostoma species. Abbreviations: AL, aperture length; AW, aperture width; BWL, length of the body whorl; PWL, penultimate whorl length; SW, spire width; TL, total length; TW, total width. 
(PWL), length of the body whorl (BWL), aperture length (AL), total width (TW), aperture width (AW), and spire width (SW). For the anatomical methodology in general we followed Simone (2001). Anatomical descriptions were based on living and preserved relaxed specimens. When necessary, a $0.1 \%$ neutral red solution was used to enhance the contrast of tissues. Internal features were examined under a Leica MZ6 stereoscopic microscope. The general descriptive format follows Simone (2001) and the terminology used follows that of Hylton Scott (1953, 1954) and Simone (2001, 2011).

Protoconchs, operculae, and radulae were also examined with a scanning electron microscope (SEMJEOL 6360). The radulae were separated from the buccal mass and cleaned following the method described by Holznagel (1998). The terminology used for radular description follows Vogler (2013). The radular formula is described as in Gomez et al. (2011): rachidian (number of left side cusps/median cusp/number of right side cusps); lateral teeth (inner cusps/pronounced cusp/outer cusps); marginal teeth (number of cusps on inner marginal tooth, and number of cusps on outer marginal tooth).

A cetyltrimethylammonium bromide protocol (Gutiérrez Gregoric et al., 2013) was used to extract genomic DNA from foot samples of specimens belonging to A. chloroticum, Aylacostoma brunneum sp. nov., and outgroup species: Doryssa sp., Pachychilus nigratus (Poey, 1858), and Pachychilus laevissimus (Sowerby, 1825). Partial sequences of the mitochondrial cytochrome oxidase subunit I (COI) and cytochrome b $(C y t b)$ genes were amplified by means of the universal primers under the conditions detailed in Table 1 . Success of PCR reactions was verified by agarose gel electrophoresis. COI products were purified using an AxyPrep PCR Clean- up Kit (Axygen Biosciences, Union City, California). Owing to the co-amplification of nonspecific fragments, $C y t b$ products were purified from $1.5 \%(\mathrm{w} / \mathrm{v})$ agarose gels through the use of a Zymoclean Gel DNA Recovery Kit (Zymo Research, Orange, California). After purification, both DNA strands for each gene were then directly cycle sequenced (Macrogen Inc., Seoul, Korea). The resulting sequences were trimmed to remove the primers, and the consensus sequences of the individuals were compared with reference sequences in GenBank through the use of the BLASTN algorithm (Altschul et $a l ., 1990)$ to identify similar sequences. Subsequently, a sequence alignment was performed separately for each mitochondrial region with the CLUSTAL X 2.0.12 software (Larkin et al., 2007), which was optimized by visual inspection and edited with a word processor.

Phylogenetic analyses were conducted in order to identify well-supported sister clades that could be potentially different species under the EGSC, namely the K/O method (Birky et al., 2010, 2011; Schön et al., 2012; Birky, 2013). This method, based on population genetic theory, has recently been used to successfully describe new species in a wide range of asexual organisms (e.g. Birky et al., 2011; Martens, Halse \& Schön, 2012; Shearn et al., 2012). The application of the species criteria was carried out following the procedure as described in Schön et al. (2012) and Birky (2013): once we identified well-supported sister clades, we then estimated the mean pairwise uncorrected sequence difference $d$ for each clade. Subsequently, we estimated the nucleotide diversity $\pi=d n /(n-1)$, where $n$ is the number of sequences in the clade. When $d=0$, we calculated $d$ as if one sequence differed from the others at one site by $d=2 / L n$, where $L$ is the sequence length.

Table 1. Primers and reaction conditions applied for the two mitochondrial markers used in this study

\begin{tabular}{|c|c|c|}
\hline Primer & Reference & Sequence $5^{\prime}-3^{\prime}$ \\
\hline \multicolumn{3}{|l|}{$\mathrm{COI}$} \\
\hline LCO1490 & Folmer et al., 1994 & GGT CAA CAA ATC ATA AAG ATA TTG G \\
\hline $\mathrm{HCO} 2198$ & Folmer et al., 1994 & TAA ACT TCA GGG TGA CCA AAA AAT CA \\
\hline \multicolumn{3}{|c|}{$\begin{array}{l}\text { Master mix (final volume } 50 \mu \mathrm{l} \text { ): } 50-100 \mathrm{ng} \text { template DNA, } 0.1 \mu \mathrm{M} \text { of each primer, } 1 \times \text { PCR buffer, } 50 \mu \mathrm{M} \text { dNTPs, } \\
1.5 \mathrm{mM} \mathrm{MgCl}_{2} \text {, and } 1.2 \mathrm{U} \text { Platinum Taq polymerase (Invitrogen, Brazil) }\end{array}$} \\
\hline \multicolumn{3}{|c|}{$\begin{array}{l}\text { PCR conditions: } 1 \mathrm{~min} \text { at } 94^{\circ} \mathrm{C} \text {; five cycles of } 1 \mathrm{~min} \text { at } 94{ }^{\circ} \mathrm{C}, 40 \mathrm{~s} \text { at } 45^{\circ} \mathrm{C}, 1 \mathrm{~min} \text { at } 72{ }^{\circ} \mathrm{C} ; 35 \text { cycles of } 30 \mathrm{~s} \text { at } 94{ }^{\circ} \mathrm{C} \text {, } \\
40 \mathrm{~s} \text { at } 51^{\circ} \mathrm{C}, 1 \mathrm{~min} \text { at } 72^{\circ} \mathrm{C} \text {; final extension for } 10 \mathrm{~min} \text { at } 72{ }^{\circ} \mathrm{C}\end{array}$} \\
\hline \multicolumn{3}{|l|}{$C y t b$} \\
\hline UCYTB151F & Merritt et al., 1998 & TGT GGR GCN ACY GTW ATY ACT AA \\
\hline UCYTB270R & Merritt et al., 1998 & AAN AGG AAR TAY CAY TCN GGY TG \\
\hline \multicolumn{3}{|c|}{$\begin{array}{l}\text { Master mix (final volume } 50 \mu \mathrm{l} \text { ): } 50-100 \mathrm{ng} \text { template DNA, } 0.5 \mu \mathrm{M} \text { of each primer, } 1 \times \text { PCR buffer, } 0.2 \mathrm{mM} \mathrm{dNTPs} \text {, } \\
1.5 \mathrm{mM} \mathrm{MgCl}_{2} \text {, and } 1 \mathrm{U} \text { Platinum Taq polymerase (Invitrogen, Brazil) }\end{array}$} \\
\hline \multicolumn{3}{|c|}{$\begin{array}{l}\text { PCR conditions: } 4 \text { min at } 94{ }^{\circ} \mathrm{C} \text {; } 38 \text { cycles of } 40 \mathrm{~s} \text { at } 94^{\circ} \mathrm{C}, 40 \mathrm{~s} \text { at } 48{ }^{\circ} \mathrm{C}, 1 \mathrm{~min} \text { at } 72{ }^{\circ} \mathrm{C} \text {; final extension for } 6 \mathrm{~min} \text { at } \\
72^{\circ} \mathrm{C}\end{array}$} \\
\hline
\end{tabular}

Cyt b, cytochrome b; COI, cytochrome oxidase subunit I; dNTPs, deoxyribonucleotide triphosphates. 
The parameter $\theta$ was estimated by $\theta=\pi /(1-4 \pi / 3)$. We then calculated the mean pairwise sequence difference between the pair of sister clades. As the pairwise sequence differences were small, we used the uncorrected sequence difference $D$ instead of $K$ (which is $D$ corrected for multiple hits), and calculated the ratio $D / \theta$ as a close approximation to $K / \theta$ (Shearn et al., 2012; Birky, 2013). In order to fulfil the $K / \theta$ criteria, sister clades must have $K / \theta \geq 4$ to be considered different species with probability $\geq 0.95$ (Birky, 2013 and references therein).

Given that we obtained $C y t b$ sequences for only a few individuals we just calculated a pairwise distance matrix for this region, and only $C O I$ data were subjected to phylogenetic analyses by the methods of neighbour-joining (NJ) and Bayesian inference (BI). The NJ analysis was conducted with MEGA 5.05 software (Tamura et al., 2011) through the use of the maximum-composite-likelihood option for computing evolutionary distances (Tamura, Nei \& Kumar, 2004). The statistical support for the resulting phylogeny was assessed by bootstrapping with 1000 replicates (Felsenstein, 1985). The BI was carried out with the MrBayes 3.2 software (Ronquist et al., 2012). Two runs were performed simultaneously with four Markov chains that went for 1000000 generations, sampling every 100 generations. The first 10000 generations of each run were discarded as burn-in, and the remaining 18000 trees were used to estimate posterior probabilities. Mean pairwise differences within and between sister clades were estimated with MEGA 5.05 using the numbers of differences (p) and 1000 bootstrap replicates.

\section{RESULTS}

Five novel sequences of $361 \mathrm{bp}$ for Cyt $b$ (A. chloroticum $=4 ; A$. brunneum sp. nov. $=1)$ and 46 sequences of $658 \mathrm{bp}$ for COI (A. chloroticum $=37$; A. brunneum $=6$; outgroup $=3$ ) were obtained in the present study. BLAST searches identified $C y t b$ and $C O I$ sequences as similar to other freshwater gastropods, excluding possible contamination with DNA from other sources. Genetic distances for $C y t b$ and COI are shown in Table 2. For COI, the two different phylogenetic analyses recovered two well-supported sister clades with high posterior probabilities and bootstrap values (Fig. 2). As required for the $K / \theta$ method, genetic differences within and between the clades were estimated (Table 3 ). The $D / \theta$ ratio obtained was 137.97 and the EGSC criteria were clearly fulfilled. Thus, both clades were recognized as distinct evolutionary genetic species.

\section{SYSTEMATICS \\ FAMily THIARIDAE GILL, 1871 \\ Genus AyLACOSTOMA SPIX, 1827}

Type species: Aylacostoma glabrum Spix, 1827, eastern Brazil.

\section{Aylacostoma CHLOROTICUM HYLTON ScotT, 1954}

(FIGS 3-6)

Aylacostoma chlorotica Hylton Scott, 1954: 45-48 (fig. 1); Castellanos, 1981: 10, 11, 17; Quintana, 1982:

Table 2. Uncorrected genetic distances for $C y t b$ and COI amongst Aylacostoma specimens

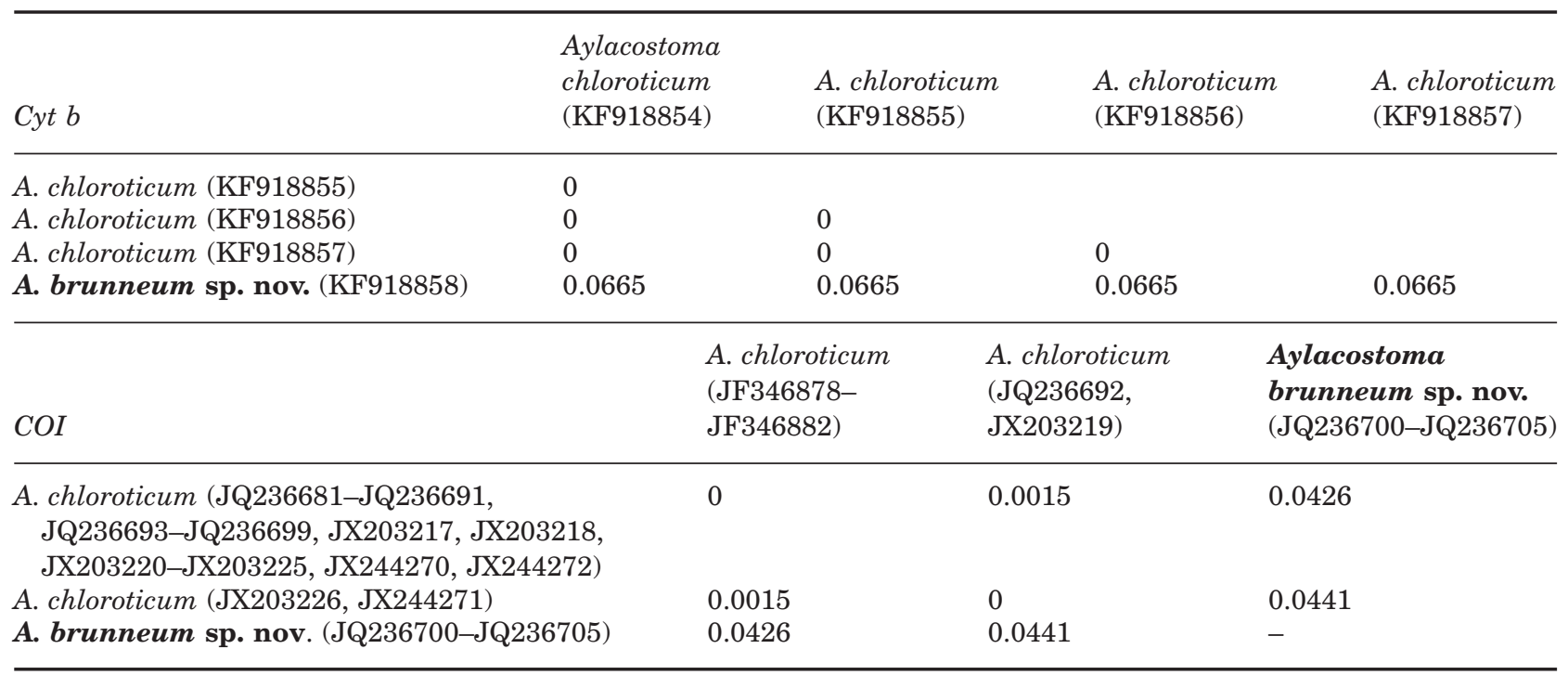

GenBank accession numbers are indicated in parentheses.

Cyt b, cytochrome b; COI, cytochrome oxidase subunit I. 


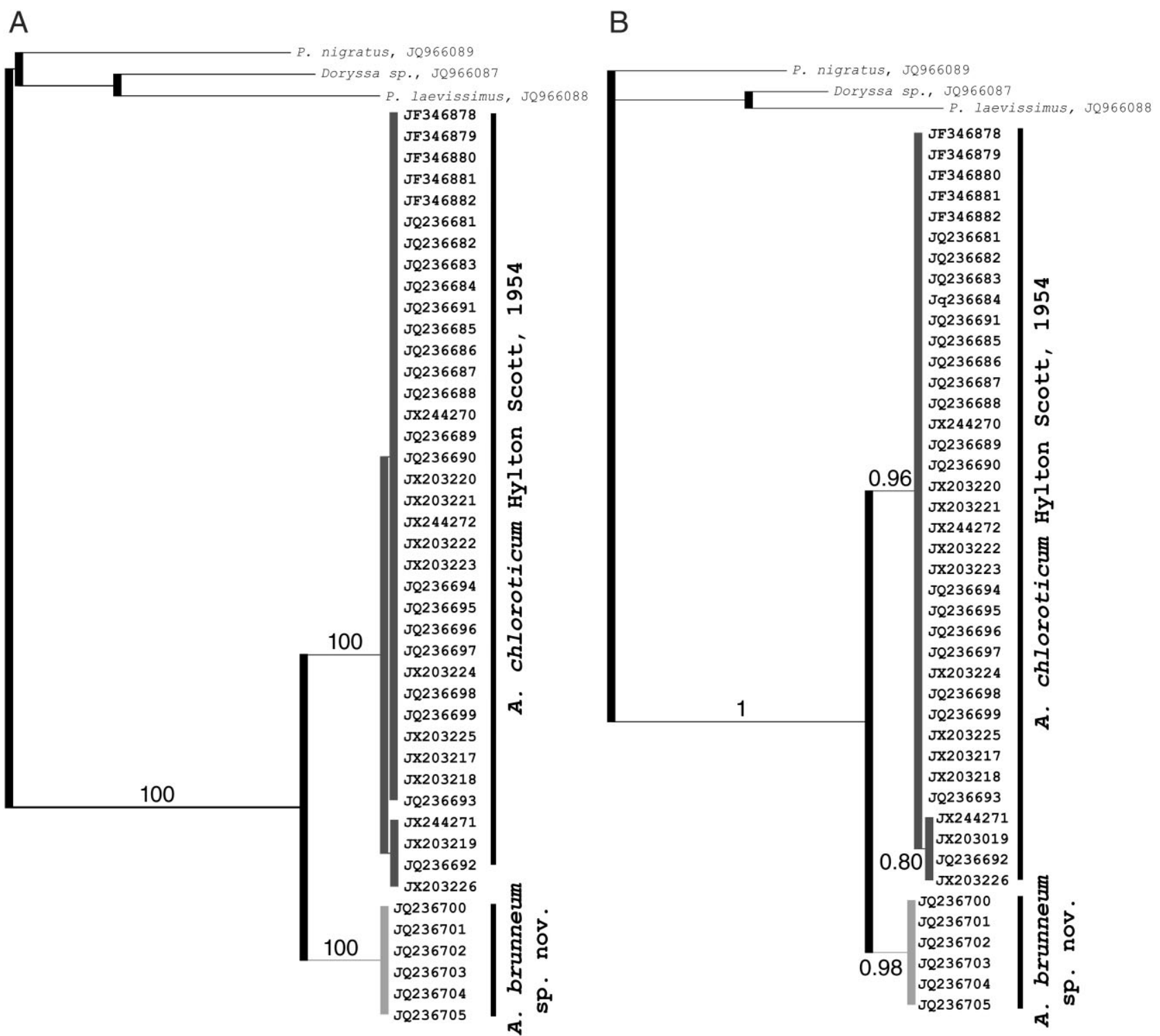

Figure 2. Phylogenetic trees of Aylacostoma (A.) specimens based on 658 nucleotides of the partial cytochrome oxidase subunit I gene. A, neighbour-joining (NJ) tree. B, Bayesian consensus tree. The support values: bootstrap values (NJ) and posterior probabilities (Bayesian inference) are shown above and below the branches. The trees show two wellsupported clades (each in a different grey), corresponding to the species described in this study. Numbers within clades are GenBank accession numbers. Abbreviation: P., Pachychilus.

Table 3. D/A ratio calculations for Aylacostoma cytochrome oxidase subunit I sequences

\begin{tabular}{lllll}
\hline & $\theta$ & $D$ & D/ $\theta$ ratio & $\mathrm{n} 1, \mathrm{n} 2$ \\
\hline Aylacostoma chloroticum - Aylacostoma brunneum sp. nov. & $0.0003096^{*}$ & 0.0427174 & 137.97 & 37,6 \\
\hline
\end{tabular}

*Birky (2013) suggested using the larger value of $\theta$. However, we used the smaller value because it was based on real data; the larger value was estimated from a clade of six identical individuals by supposing that one sequence differed from each of the others at one site.

$\theta$, mean pairwise sequence difference within a clade; $D$, mean pairwise sequence difference between sister clades; n1, number of sequences within the Aylacostoma chloroticum clade; n2, number of sequences within the Aylacostoma brunneum sp. nov. clade. 


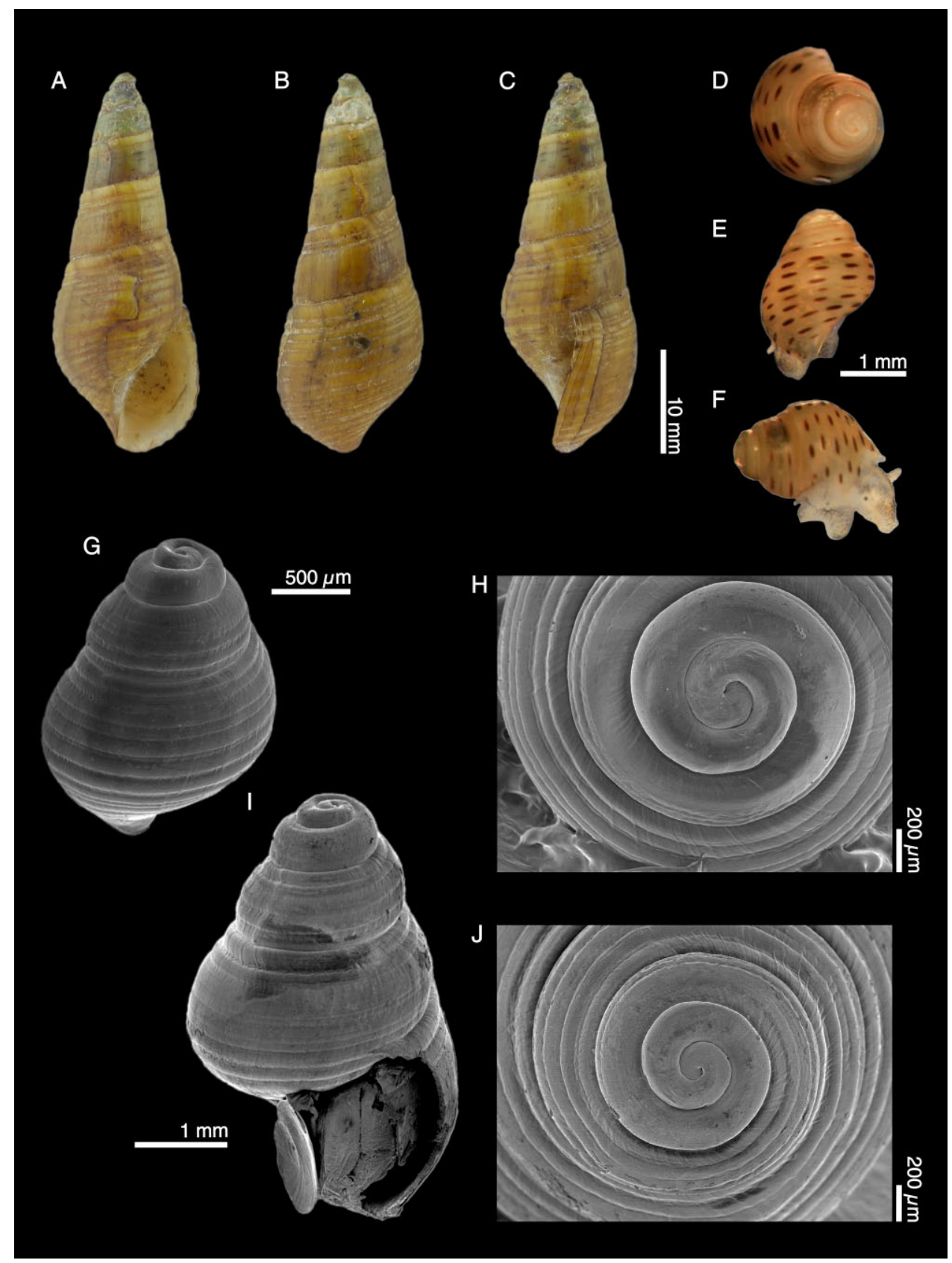

Figure 3. Shell of Aylacostoma chloroticum. A-C, holotype (MLP 10958): A, frontal, B, dorsal, and C, lateral view. D-J, juveniles from brood pouch and protoconch views. D-F, stereoscopic microscope: D, apical-lateral, E, dorsal, and F, lateral view. G-J, scanning electron micrographs: G, dorsal, I, frontal, and H, J, apical view.

118; Castellanos \& Landoni, 1995: 774, 796 (fig. 34); Rumi et al., 2004: 214; Simone, 2006: 12, 79 (fig. 185).

Aylacostoma chloroticum - Cazzaniga, 1992: 303; Quintana \& Mercado Laczkó, 1997: 26 (fig. 4); Mansur, 2000c; Quintana, Peso \& Pérez, 2001: 110; Gutiérrez Gregoric et al., 2006: 54, 57; Rumi et al., 2006: 199, 204; Gutiérrez Gregoric et al., 2007: 109; Ostrowski de Núñez \& Quintana, 2008: 647, 648, 652-654 (fig. 1);
Rumi et al., 2008: 80; Núñez, Gutiérrez Gregoric \& Rumi, 2010: 50, 58; Cazzaniga, 2011: 178; Vogler, 2012: 43-45 (fig. 1); Vogler et al., 2012: passim (fig. 1b).

Hemisinus chloroticus - Martín \& César, 2004: 15.

Type locality

'Isla Ibicuy, Alto Paraná, Paraguay'. At present, the Isla Ibicuy $\left(27^{\circ} 16^{\prime}-27^{\circ} 19^{\prime} \mathrm{S}, 56^{\circ} 04^{\prime}-56^{\circ} 14^{\prime} \mathrm{W}\right)$, as well 

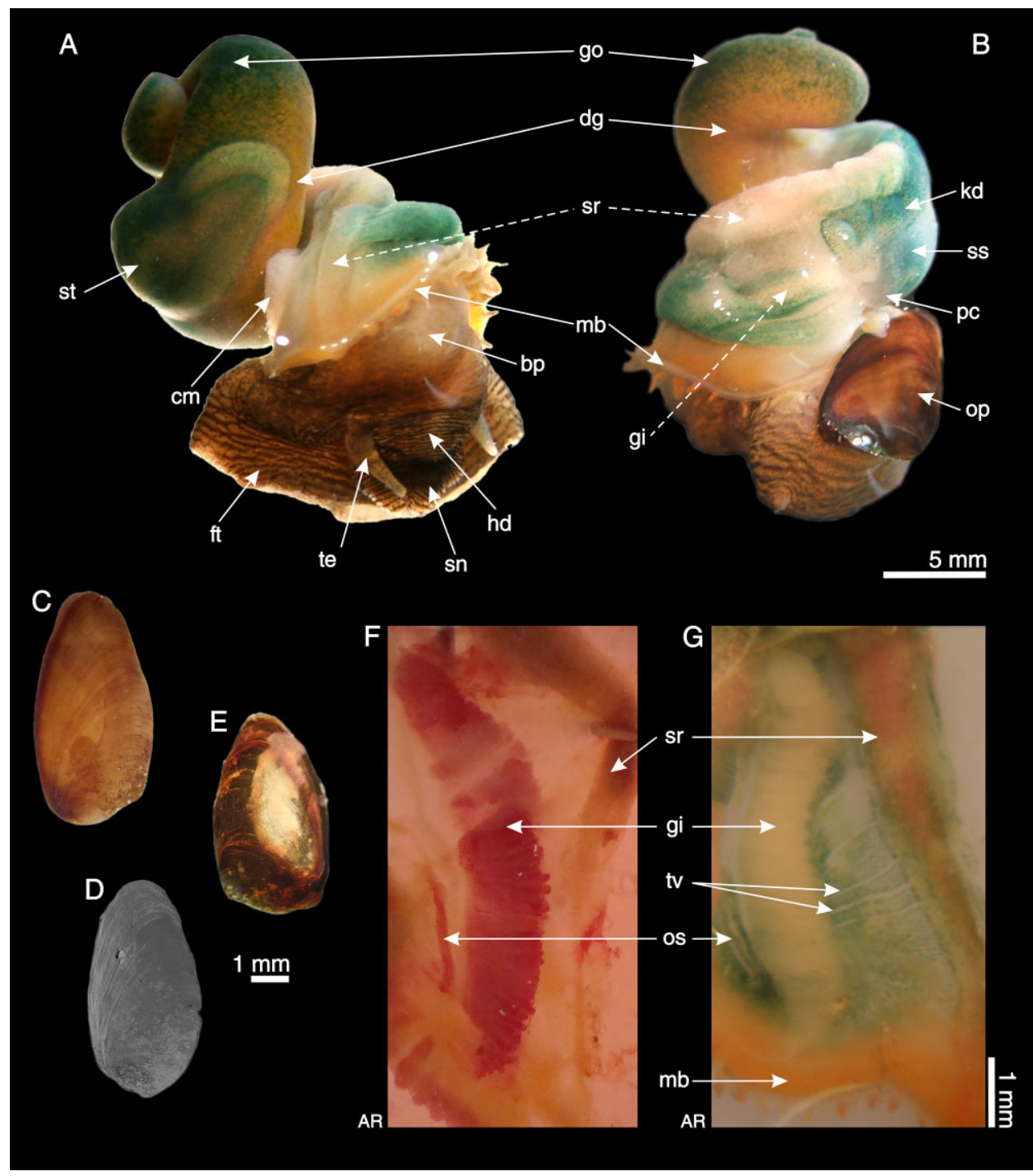

Figure 4. Anatomy of Aylacostoma chloroticum. A, B, specimen extracted from the shell: A, dorsolateral right view; B, ventrolateral left view. C-E, operculum: C, D, external view, stereoscopic microscope and scanning electron microscope, respectively; E, internal view, stereoscopic microscope. F, G, detail of mantle organs, inner-ventral view: F, fixed and stained with neutral red; G, live. Dashed arrows indicate internal structures. Abbreviations: AR, anterior region; bp, brood pouch; cm, columellar muscle; dg, digestive gland; ft, foot; gi, gill; go, gonad; hd, head; kd, kidney; mb, mantle border; op, operculum; os, osphradium; pc, pericardial chamber; sn, snout; sr, adrectal sinus; ss, style sac; st, stomach; te, cephalic tentacle; tv, transverse vessels between gill and adrectal sinus.

as many other islands of the High Paraná River between Argentina and Paraguay have disappeared because of damming and the filling up of the Yacyretá Reservoir in the early 1990s (Vogler, 2013).

\section{Type material}

Holotype: MLP 10958 (examined; dry shell from type locality; Fig. 3A-C); paratypes (all from type locality): MACN 488-1 (236 dry shells, examined); MLP 11596 (12 juvenile shells and two operculae, examined).

\section{Other material examined}

PARAGUAY. Itapúa; Río Beach $\left(27^{\circ} 24^{\prime} 29.83^{\prime \prime} \mathrm{S}\right.$, $55^{\circ} 49^{\prime} 32.94^{\prime \prime}$ ) ): MLP 13521 (one soft part in RaillietHenry's fluid), 13522 (one soft part in RaillietHenry's fluid), 13523 (six unbroken juvenile shells with soft parts in 96\% ethanol), 13762 (three soft parts in Railliet-Henry's fluid); conservation programme at UNaM (seven living specimens). ARGENTINA. Corrientes; Apipé Rapids ( $\left.27^{\circ} 28^{\prime} 57.41^{\prime \prime} \mathrm{S}, 56^{\circ} 44^{\prime} 0.82^{\prime \prime} \mathrm{W}\right)$ : conservation programme at UNaM (five living specimens). Misiones; Posadas Port $\left(27^{\circ} 21^{\prime} 43.10^{\prime \prime} \mathrm{S}\right.$, 


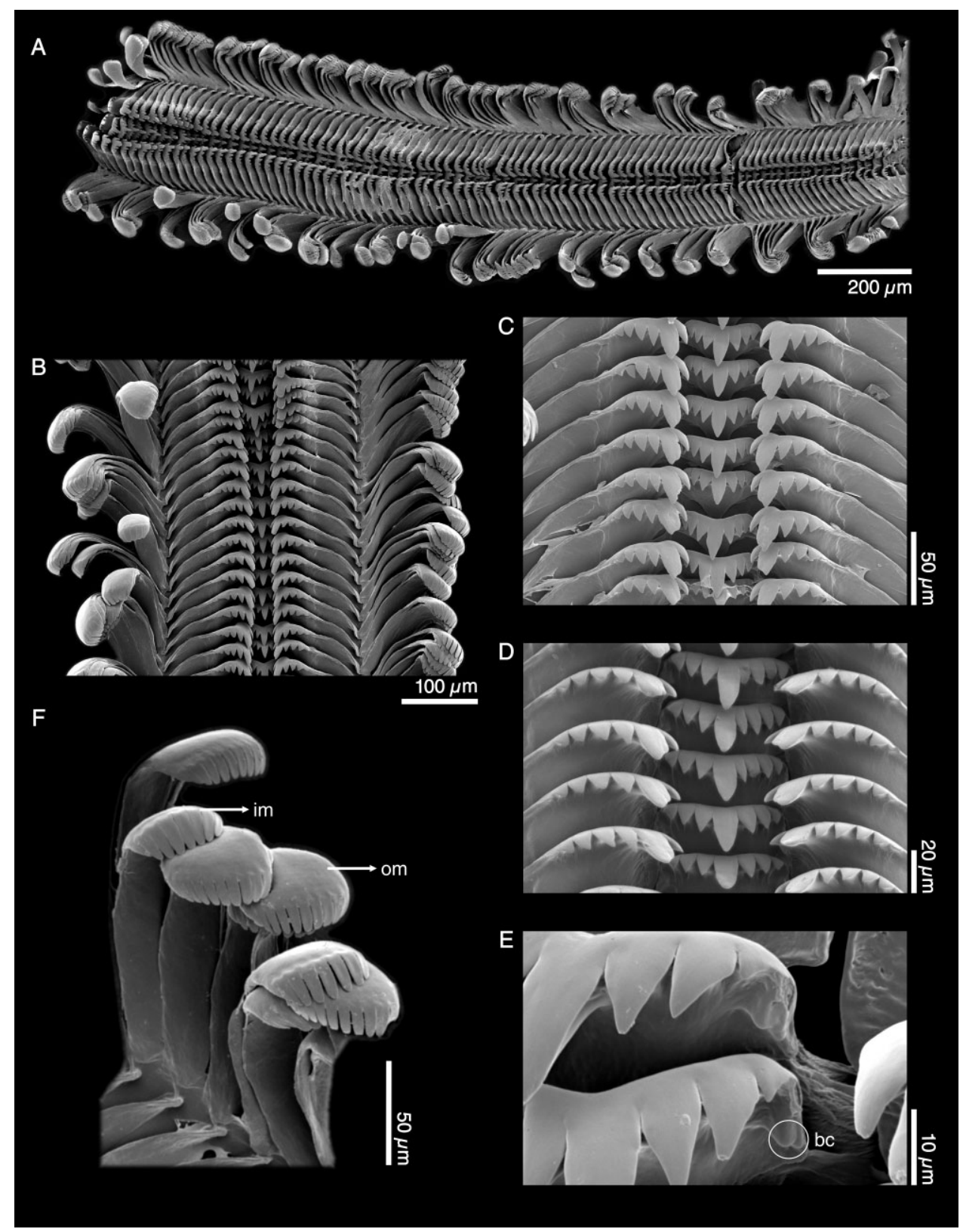

Figure 5. Scanning electron micrographs of radula of Aylacostoma chloroticum. A, radular ribbon. B, radular segment. C, D, detail showing central and lateral teeth. E, rachidian with basal cusps. F, marginal teeth. Abbreviations: bc, basal cusps; im, inner marginal; om, outer marginal.

$\left.55^{\circ} 53^{\prime} 5.20^{\prime \prime} \mathrm{W}\right)$ : conservation programme at UNaM (three specimens); San José Lagoon $\left(27^{\circ} 22^{\prime} 11.40^{\prime \prime} \mathrm{S}\right.$, $55^{\circ} 52^{\prime} 49.64^{\prime \prime} \mathrm{W}$ ): conservation programme at UNaM (ten living specimens); Candelaria (27 $26^{\prime} 50.96^{\prime \prime} \mathrm{S}$, $55^{\circ} 45^{\prime} 0.84^{\prime \prime} \mathrm{W}$ ): conservation programme at UNaM (ten living specimens); mouth of San Juan Stream $\left(27^{\circ} 25^{\prime} 0.95^{\prime \prime} \mathrm{S}, 55^{\circ} 42^{\prime} 46.88^{\prime \prime} \mathrm{W}\right)$ : conservation programme at UNaM (two living specimens). Additional material: four lots from three localities, 36 shell speci- mens at MLP; anatomical material from various individuals from Candelaria, Misiones, Argentina and Río Beach, Itapúa, Paraguay.

\section{Taxonomic history}

According to Hylton Scott's (1954) original description, the holotype and paratypes were deposited at the MACN under no. 488-1. Tablado \& Mantinian (2004) reported that the holotype was not found amongst the 


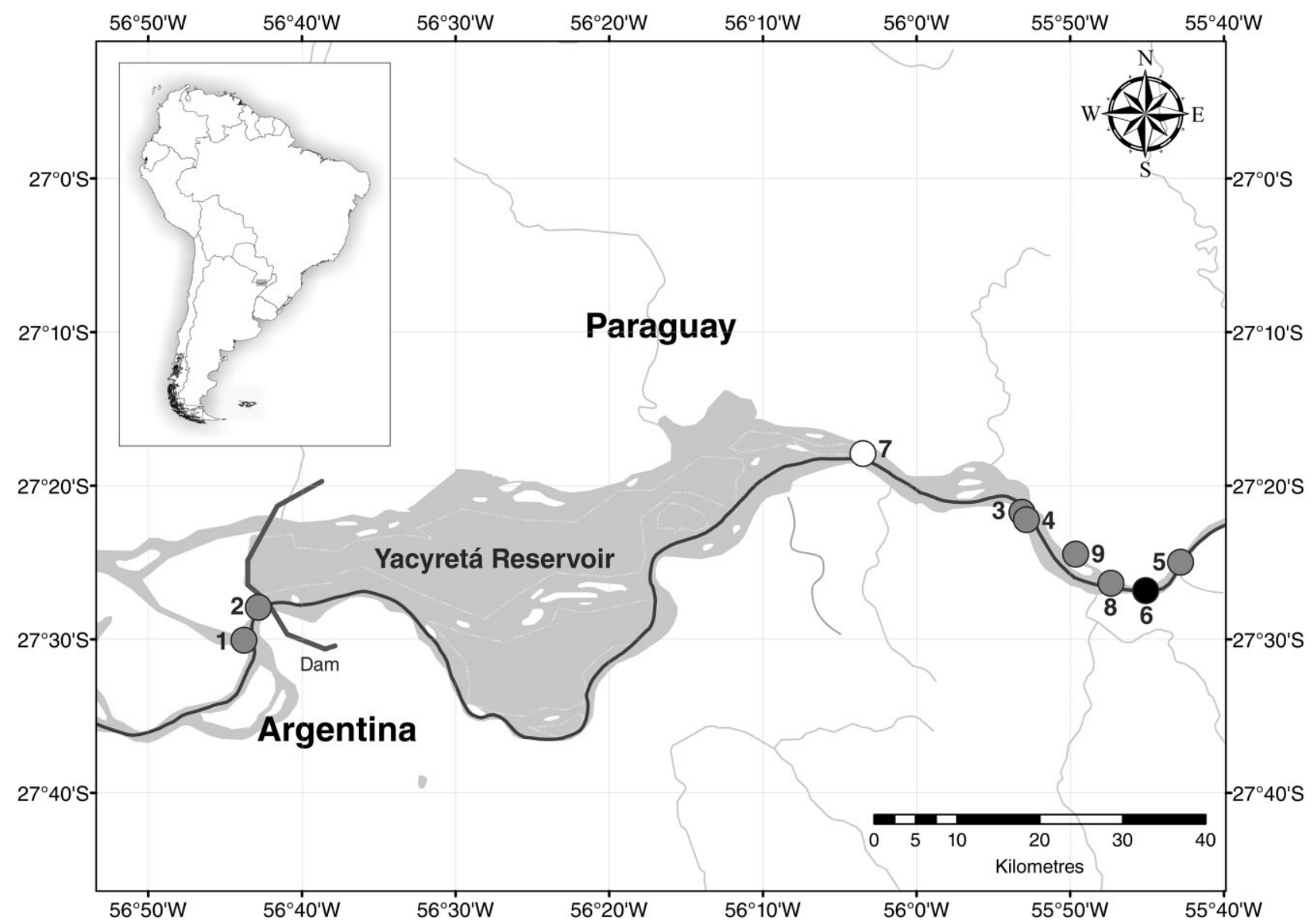

Figure 6. Distribution of Aylacostoma chloroticum in the High Paraná River. Type locality (no. 7) shown in white. Location numbers correspond to the numbers in Table 5. Localities 1, 2, 7, and 8: historical records prior to the damming and filling up of the Yacyretá Reservoir. Localities 3, 4, 5, 6, and 9: records obtained during the successive stages of the filling up of the reservoir. Locality 6 (shown in black): only known wild population after completion of the filling up process in 2011.

type specimens housed in the National Invertebrate Collection at the MACN. For unknown reasons the holotype is deposited in the Type Specimens Collection at the MLP under no. 10958. This specimen is the same as that measured and shown in Hylton Scott (1954), which was also illustrated in Simone (2006), and photographed in this study.

\section{Description}

Shell (Fig. 3): Shape conical to fusiform; strong; apex worn, sometimes completely eroded; large size, reaching up to at least $42 \mathrm{~mm}$ (Table 4). Colour: greenish-yellow to mid greenish-brown; some specimens bearing reddish dark brown, minute, spiral spots. Protoconch present only in juveniles (from brood pouch) with two whorls smooth, convex, rounded; spiral sculpture beginning gradually from third whorl, becoming sharp in successive whorls (Fig. 3G-J). From embryonic stages juveniles always with delicate red wine colour spots, except for subsutural band, which has no decoration (Fig. 3D-F). Teleoconch with up to eight whorls, in most cases with three to five persistent whorls. Spire high with flat-convex whorls; body whorl moderately convex. Surface sculptured with spiral nearly flat cords somewhat irregular in each whorl, about six in penultimate whorl; narrow furrow amongst spiral cords. Some specimens with sculpture attenuated, up to whorls entirely smooth. Subsutural cord a little wider than other cords, sometimes lighter. Suture shallow, not excavated. Aperture elliptical, long, internally white, angled posteriorly, with shallow anterior canal.

Head-foot (Fig. 4A, B): Head, snout, tentacles, and dorsal region of foot light to mid-brown, with dark brown transverse striae. Snout large, dorsoventrally 
Table 4. Shell measurements of Aylacostoma chloroticum from the holotype, and 17 living specimens included in the conservation programme taking place at Universidad Nacional de Misiones (UNaM; Posadas, Argentina)

\begin{tabular}{lccccrrrrl}
\hline & TL & TW & BWL & PWL & SW & AL & AW & NW & Location \\
\hline Holotype, MLP 10958 & 34.78 & 13.43 & 19.38 & 5.74 & 9.46 & 14.35 & 6.10 & 6 & Isla Ibicuy, PY \\
Specimen no. 1 & 41.59 & 16.13 & 20.95 & 6.22 & 10.43 & 16.02 & 7.07 & 8 & San Juan St., AR \\
Specimen no. 2 & 40.49 & 14.5 & 19.91 & 5.82 & 10.18 & 15.32 & 7.12 & 7 & San Juan St., AR \\
Specimen no. 3 & 33.59 & 11.20 & 17.08 & 5.19 & 8.11 & 12.86 & 5.66 & 7 & Candelaria, AR \\
Specimen no. 4 & 32.07 & 12.12 & 17.90 & 4.60 & 8.35 & 13.17 & 6.20 & 6 & Candelaria, AR \\
Specimen no. 5 & 30.11 & 14.05 & 19.29 & 5.25 & 9.33 & 14.88 & 6.55 & 4 & Candelaria, AR \\
Specimen no. 6 & 29.54 & 10.20 & 15.92 & 3.45 & 7.26 & 12.17 & 5.26 & 6 & Candelaria, AR \\
Specimen no. 7 & 29.29 & 10.40 & 16.63 & 4.04 & 7.14 & 13.01 & 5.10 & 6 & Candelaria, AR \\
Specimen no. 8 & 29.20 & 11.47 & 17.64 & 4.56 & 8.34 & 12.52 & 5.29 & 5 & Candelaria, AR \\
Specimen no. 9 & 26.72 & 9.82 & 15.89 & 4.02 & 6.97 & 11.76 & 5.01 & 5 & Candelaria, AR \\
Specimen no. 10 & 24.96 & 10.19 & 15.38 & 4.04 & 7.20 & 11.30 & 5.68 & 5 & Candelaria, AR \\
Specimen no. 11 & 24.68 & 8.65 & 14.02 & 3.86 & 6.49 & 9.81 & 4.67 & 5 & Candelaria, AR \\
Specimen no. 12 & 23.70 & 8.72 & 13.80 & 3.58 & 6.33 & 10.06 & 4.72 & 5 & Candelaria, AR \\
Specimen no. 13 & 22.84 & 10.28 & 15.27 & 4.08 & 6.87 & 11.42 & 5.80 & 4 & Río Beach, PY \\
Specimen no. 14 & 22.20 & 10.14 & 14.88 & 3.81 & 6.82 & 10.74 & 5.80 & 3 & Río Beach, PY \\
Specimen no. 15 & 21.45 & 9.60 & 14.08 & 4.09 & 6.50 & 10.45 & 5.43 & 4 & Río Beach, PY \\
Specimen no. 16 & 21.01 & 9.14 & 14.40 & 3.60 & 6.22 & 10.99 & 5.27 & 3 & Río Beach, PY \\
Specimen no. 17 & 20.90 & 8.95 & 13.67 & 3.73 & 6.33 & 10.64 & 5.13 & 4 & Río Beach, PY \\
\hline
\end{tabular}

Measurements in $\mathrm{mm}$.

TL, total length; TW, total width; BWL, length of body whorl; PWL, penultimate whorl length; SW, spire width; AL, aperture length; AW, aperture width; NW, number of whorls; AR, Argentina; PY, Paraguay.

References to localities are provided in the main text in the Other material examined section for the species.

flattened, anterior margin somewhat bilobed. Tentacles long, thick, eyes on outer side of ocular peduncles. Foot of medium size, without divisions; anterior pedal gland a furrow on anterior edge of foot. Brood pouch situated on posterior region of head, extending into neck region; several specimens with developing embryos inside. Aperture of brood pouch ventrally situated near right fusion of mantle to head-foot. Columellar muscle of about one and a half whorls.

Operculum (Fig. 4C-E): Ovate, corneous, brown, paucispiral with nucleus subterminal, externally lamellate. Muscle scar elliptical, near inner margin.

Mantle organs: Mantle border with small papillae (Fig. 4A), more developed at both extremities. Mantle cavity of about two whorls. Osphradium conspicuous, ridge-like, lying on left side of mantle cavity, less than half of gill length; anterior extremity posterior to that of gill (Fig. 4F, G). Gill very long, almost same length as pallial cavity; filaments triangular; ctenidial vein well developed. Area between gill and rectum without distinctive vascularization in all fixed specimens; but some living specimens with distinct transverse vessels; hypobranchial gland located in same area. Adrectal sinus proportionally broad with rectum running free inside.
Pallial oviduct running through right side of pallial cavity.

Digestive system: Mouth longitudinal, ventral, at anterior extremity of the snout. Buccal mass situated within snout, just behind mouth; oesophagus dorsal, odontophore ventral. Radula taenioglossate, short, $\mathrm{S}$-shaped in side view, with about 93 rows of teeth $(N=6$; Fig. $5 \mathrm{~A})$. Rachidian teeth pentagonal, broader than longer, with v-shaped base. All of rachidian bearing pointed apical cusps (3-4/1/4-3), central cusp noticeably longer, lanceolate (Fig. 5B-D); rachidian with two basal cusps at each outer corner (Fig. 5E). Lateral teeth long, in general with six to seven pointed cusps, second one larger, somewhat rectangular (1/1/4-5; Fig. 5B-D). Marginal teeth similar to one another, long, spatulate, narrow on base, with slender, fringe-like cusps. Inner marginal teeth with about eight cusps; outer marginals with about 11 thinner cusps (Fig. 5F). Stomach large, complex, about half whorl, separating almost completely digestive gland-gonad from pericardial and pallial structures. Style sac large, about half of stomach size. Style elliptical, transparent. Digestive gland of about two whorls, posterior to stomach. Intestine long, narrow, with dorsal loop on style sac. Rectum broad, with several inner folds. Anus siphoned, in right extremity of mantle border, posterior to anterior end of pallial oviduct. 
Table 5. Historical records of Aylacostoma chloroticum in Argentina and Paraguay

\begin{tabular}{|c|c|c|c|c|c|c|}
\hline Country & No. & Locality & Year & Latitude & Longitude & Reference \\
\hline \multirow[t]{6}{*}{ Argentina } & 1 & Isla Apipé Grande & 1981 & $27^{\circ} 30^{\prime} 5.4^{\prime \prime} \mathrm{S}$ & $56^{\circ} 43^{\prime} 45.48^{\prime \prime} \mathrm{W}$ & Castellanos, 1981 \\
\hline & 2 & Apipé Rapids & 1994 & $27^{\circ} 28^{\prime} 57.41^{\prime \prime} \mathrm{S}$ & $56^{\circ} 44^{\prime} 0.82^{\prime \prime} \mathrm{W}$ & $\begin{array}{l}\text { Quintana \& Mercado } \\
\text { Laczkó, } 1997\end{array}$ \\
\hline & 3 & Posadas Port & 2006 & $27^{\circ} 21^{\prime} 43.10^{\prime \prime} \mathrm{S}$ & $55^{\circ} 53^{\prime} 5.20^{\prime \prime} \mathrm{W}$ & This work \\
\hline & 4 & San José Lagoon & 2008 & $27^{\circ} 22^{\prime} 11.40^{\prime \prime} \mathrm{S}$ & $55^{\circ} 52^{\prime} 49.64^{\prime \prime} \mathrm{W}$ & This work \\
\hline & 5 & San Juan Stream (mouth) & 2009 & $27^{\circ} 25^{\prime} 0.95^{\prime \prime} \mathrm{S}$ & $55^{\circ} 42^{\prime} 46.88^{\prime \prime} \mathrm{W}$ & This work \\
\hline & 6 & Candelaria & 2006-2013 & $27^{\circ} 26^{\prime} 50.96^{\prime \prime} \mathrm{S}$ & $55^{\circ} 45^{\prime} 0.84^{\prime \prime} \mathrm{W}$ & Vogler, 2012; this work \\
\hline \multirow[t]{4}{*}{ Paraguay } & 7 & Isla Ibicuy* & 1954 & $27^{\circ} 17^{\prime} 56.76^{\prime \prime} \mathrm{S}$ & $56^{\circ} 3^{\prime} 28.44^{\prime \prime} \mathrm{W}$ & Hylton Scott, 1954 \\
\hline & & & 1982 & & & Quintana, 1982 \\
\hline & 8 & Campichuelo & 1982 & $27^{\circ} 26^{\prime} 20.04^{\prime \prime} \mathrm{S}$ & $55^{\circ} 47^{\prime} 18.24^{\prime \prime} \mathrm{W}$ & Quintana, 1982 \\
\hline & 9 & Río Beach & 2007 & $27^{\circ} 24^{\prime} 29.83^{\prime \prime} \mathrm{S}$ & $55^{\circ} 49^{\prime} 32.94^{\prime \prime} \mathrm{W}$ & This work \\
\hline
\end{tabular}

*Type locality. The coordinates of localities $1,2,7$, and 8 are approximations; only the localities' names were reported in the consulted sources and the precise locations are uncertain.

Circulatory and excretory systems: Heart situated posteriorly in pallial cavity behind gill; auricle somewhat triangular, large, anterior; ventricle spherical, small, posterior. Kidney proportionally large, situated posterior to pallial cavity, limited behind by digestive gland and style sac, anterior end extending into mantle roof.

Genital system: Only females found. Ovary developed in largest specimens, occupying the superior regions of each whorl on digestive gland. Pallial oviduct complex, anterior extremity posterior to anus, close to aperture of brood pouch. Brood pouch a bulging sac situated behind head (Fig. 4A). Surface internally smooth, without conspicuous folds. Up to 13 juveniles within brood pouch occurring at different growth stages, from one to three whorls; mucus not visible around juveniles, but with transparent membrane present in oneand two-whorled specimens. Aperture of brood pouch sphincter-like.

\section{Distribution}

Neotropical species endemic to the High Paraná River, between Argentina and Paraguay. Its historical distribution was within the Argentinean Misionerean Gastropod Province (Núñez, Gutiérrez Gregoric \& Rumi, 2010 ), and comprised a narrow geographical range between $56^{\circ} 50^{\prime} \mathrm{W}$ and $55^{\circ} 40^{\prime} \mathrm{W}$ longitude $(<150 \mathrm{~km}$; Table 5, Fig. 6). The area was characterized by numerous small islands, shallow waters, and rapids (Quintana \& Mercado Laczkó, 1997). The damming and filling up of the Yacyretá Reservoir (ArgentinaParaguay) from 1993 to 2011 had a negative impact on the distribution of the species, which is currently restricted to only one known wild population in Candelaria city (Misiones, Argentina). The relict population occurs in a small and fragile habitat under several anthropogenic threats because of the construction of an artificial beach for human recreation in the area.

\section{DNA barcoding}

Partial sequences of mitochondrial $C O I(N=37)$ and Cyt $b(N=4)$ genes for specimens from several locations have been deposited in GenBank under the following accession numbers: COI: JF346878-JF346882; JQ236681-JQ236699; JX203217-JX203226; JX244270JX244272. Cyt b: KF918854-KF918857.

\section{Parasitism}

Stephanoprora aylacostoma, a digenean species was recently described from infected specimens (Ostrowski de Núñez \& Quintana, 2008). This parasite is frequently found in the gonads; but in heavy infections cercaria may also be numerous in the pallial cavity.

\section{Conservation status}

Representatives of several wild populations that were extinct are successfully being reproduced in captivity within the 'Aylacostoma Project', the ex situ conservation programme developed in the 1990s being conducted by the UNaM and the MACN, and supported by EBY. Aylacostoma chloroticum is listed by IUCN as 'Extinct in the Wild' (Mansur, 2000c).

\section{Aylacostoma brunneum Vogler \& Peso SP. Nov.} (FIGS 7-11)

Type material

Holotype (Fig. 7A-E; Table 6): MLP 13757, iii.2007, Peso, J.G. col., female, $24.98 \mathrm{~mm}$, dissected, voucher pedal tissue preserved in the tissue collection at the Museo de La Plata. Paratypes (Fig. 7F-Q; Table 6): MLP 13758 (one dry shell from type locality), 13613 (15 dry shells and two unbroken shells with soft parts in $96 \%$ ethanol 


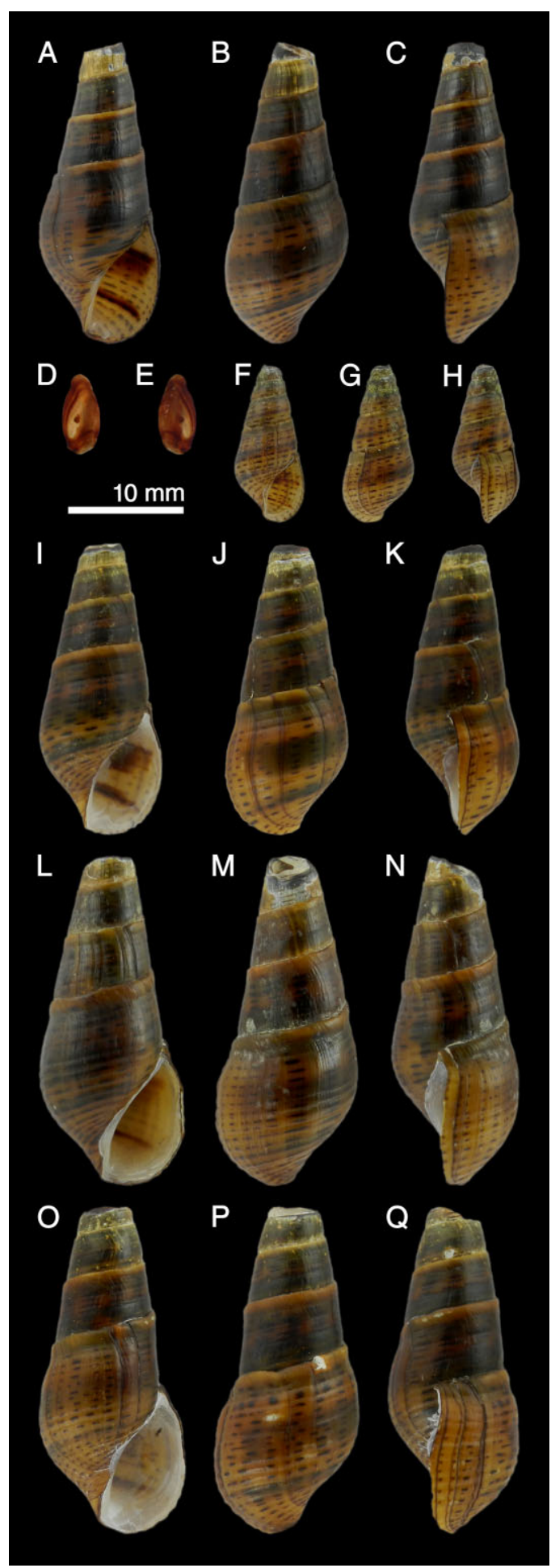

Figure 7. Aylacostoma brunneum sp. nov. A-E, holotype (MLP 13757). F-H, paratype no. 16, juvenile (MLP 13613). I-K, paratype no. 12 (MLP 13613). L-N, paratype no. 1 (MLP 13613). O-Q, paratype no. 7 (MLP 13613). A, F, I, L, O, frontal; B, G, J, M, P, dorsal; C, H, K, N, Q, lateral view. Measurements in Table 6. Operculum: $\mathrm{D}$, external view; $\mathrm{E}$, internal view. from Ita Cuá, High Paraná River; Itapúa; Paraguay; $\left.27^{\circ} 24^{\prime} 42.13^{\prime \prime} \mathrm{S}, 55^{\circ} 48^{\prime} 45.69^{\prime \prime} \mathrm{W}\right)$.

\section{Type locality}

High Paraná River; Paraguay, Itapúa, Río Beach, $27^{\circ} 24^{\prime} 29.83^{\prime \prime} \mathrm{S}, 55^{\circ} 49^{\prime} 32.94^{\prime \prime} \mathrm{W}$.

\section{Other material examined}

PARAGUAY, Itapúa; Río Beach $\left(27^{\circ} 24^{\prime} 29.83^{\prime \prime}\right.$, $55^{\circ} 49^{\prime} 32.94^{\prime \prime} \mathrm{W}$ ): MLP 13759 (one juvenile shell from brood pouch of a specimen from the type locality), conservation programme at UNaM (four living specimens); Ita Cuá $\left(27^{\circ} 24^{\prime} 42.13^{\prime \prime} \mathrm{S}, 55^{\circ} 48^{\prime} 45.69^{\prime \prime} \mathrm{W}\right)$ : MLP 13761 (two soft parts in Railliet-Henry's fluid), conservation programme at UNaM (four living specimens born in captivity from wild progenitors). Additional material: Three lots from two localities containing five shell specimens and two soft parts at MLP; descriptive anatomy from several individuals from type locality and Ita Cuá.

\section{Etymology}

Allusion to the shell colour. From the Latin word 'brunneum', meaning 'brown'. Grammatical gender: neuter.

\section{Diagnosis}

Shell dark brown with alternating lighter brown bands, decorated by reddish dark brown, minute, spiral spots; surface with opaque sheen. Osphradium conspicuous, almost half of gill length; area between gill and adrectal sinus with distinctive transverse vessels. Rachidian with tip of central cusp constricted, daggerlike. COI: GenBank JQ236705. Cyt b: GenBank KF918858.

\section{Description}

Shell (Figs 7, 8): Shape conical to ovate; strong; apex worn, sometimes completely eroded; medium size, reaching up to at least $28 \mathrm{~mm}$ (Table 6). Periostracum persistent. Colour: dark brown with alternating lighter bands, delicately decorated by reddish dark brown, minute, spiral spots regularly spaced in all specimens (Fig. 7). Protoconch present only in juveniles (from brood pouch) with two whorls almost smooth, convex, rounded; spiral sculpture beginning gradually from third whorl, with dark spiral spots, quite regularly spaced (Fig. 8). Teleoconch with up to five whorls, in most cases with three persistent whorls. Spire high, profile of whorls flattened, body whorl moderately convex. Surface with opaque sheen; spiral sculpture weak, almost absent on spire, body whorl sculptured by broad spiral cords, uniform in size with narrow and shallow furrow between; suture narrow and shallow, not excavated; small furrow running parallel to suture clearly limiting lighter subsutural cord, somewhat broad. 


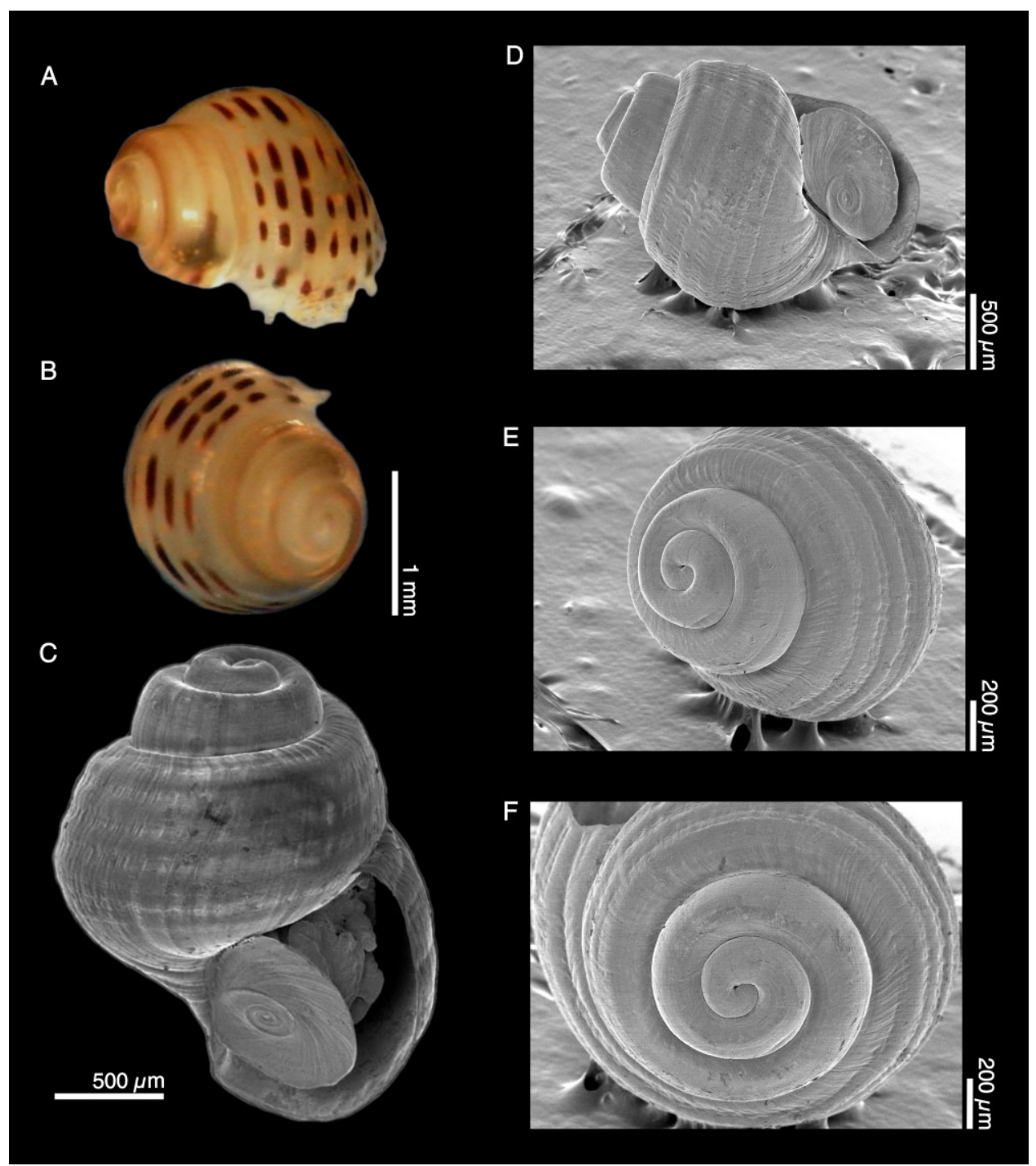

Figure 8. Juvenile of Aylacostoma brunneum sp. nov. from brood pouch and protoconch views (MLP 13759); A, B, stereoscopic microscope: A, lateral-dorsal, B, apical-lateral view. C-F, scanning electron micrographs: C, D, frontal, E, apical-lateral, F, apical view.

Aperture vertically elongated, angled posteriorly, with anterior canal defined. Outer lip D-shaped, curvature projecting towards base. When not calcified, aperture glossy with dark, linear spiral spots showing through; some specimens with two darker bands similar to slats, ending just before the edge.

Head-foot: Similar to that of preceding species. Transverse striae in cephalic region comparatively darker.

Operculum (Figs $7 D, E$; $8 C, D$ ): Similar to that of preceding species.

Mantle organs: Similar to those of preceding species. Comparatively, more transparent mantle. Osphradium length approximately half of gill length. Area between gill and adrectal sinus also with distinctive transverse vessels (Fig. 9).

Digestive system: Characters similar to previous species. Radula short, with about 94 rows of teeth $(N=3$; Fig. 10A). Rachidian teeth pentagonal, broader than longer, with v-shaped base. All of rachidian bearing pointed apical cusps (3-4/1/4-3); central cusp noticeably longer, lanceolate, with tip constricted, daggerlike (Fig. 10B-E); rachidian with two basal cusps at each outer corner (Fig. 10E). Lateral teeth long, in general with six pointed cusps, main cusp larger, somewhat rectangular, with asymmetrically lobate margin and small posterior projection (1/1/4; Fig. 10B-D); teeth 


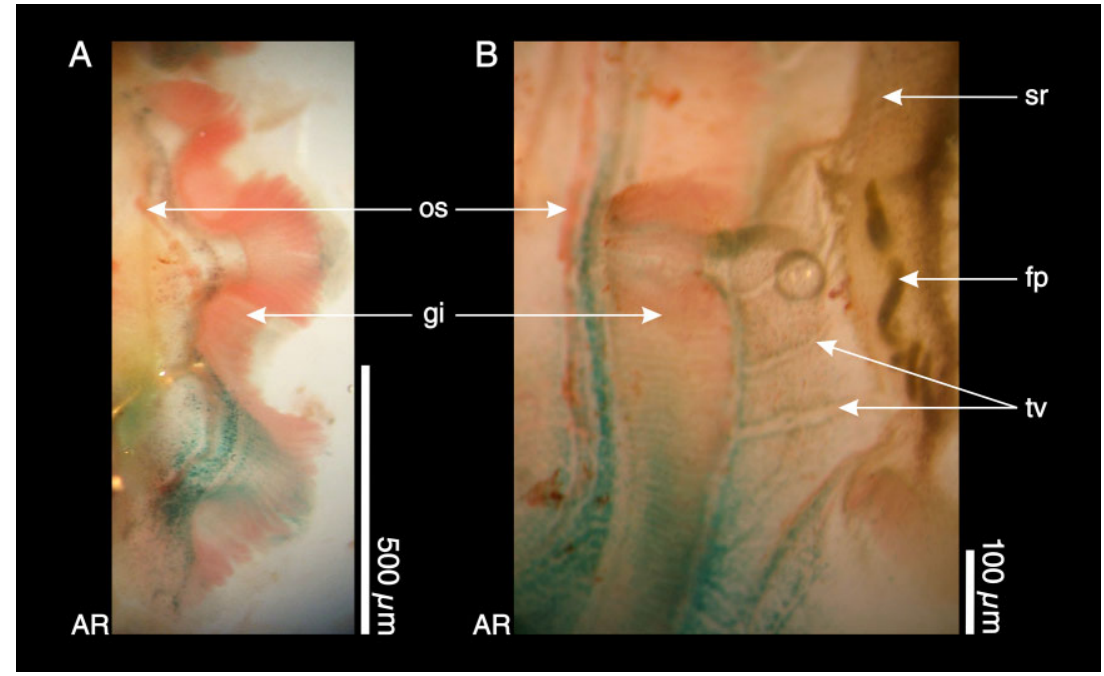

Figure 9. Mantle organs of Aylacostoma brunneum sp. nov., inner-ventral view. A, gill and osphradium. B, detail of transverse vessels between the gill and adrectal sinus. Abbreviations: AR, anterior region; fp, faecal pellet; gi, gill; os, osphradium; sr, adrectal sinus; tv, transverse vessels between gill and adrectal sinus.

Table 6. Shell measurements of the type series of Aylacostoma brunneum sp. nov.

\begin{tabular}{|c|c|c|c|c|c|c|c|c|c|}
\hline & Collection & TL & TW & BWL & PWL & SW & $\mathrm{AL}$ & AW & NW \\
\hline Holotype & MLP13757 & 24.98 & 9.99 & 15.78 & 3.98 & 7.25 & 11.58 & 4.86 & 4 \\
\hline Paratype no. 1 & MLP13613 & 26.95 & 11.28 & 17.41 & 4.70 & 8.09 & 12.61 & 5.80 & 4 \\
\hline Paratype no. 2 & MLP13613 & 27.89 & 12.38 & 18.41 & 4.39 & 9.24 & 13.72 & 6.51 & 4 \\
\hline Paratype no. $3^{*}$ & MLP13613 & 13.47 & 6.32 & 9.52 & 2.15 & 4.66 & 6.80 & 3.61 & 3 \\
\hline Paratype no. 4 & MLP13613 & 23.63 & 11.47 & 17.33 & 4.57 & 7.90 & 11.99 & 5.56 & 3 \\
\hline Paratype no. 5 & MLP13613 & 23.56 & 11.80 & 17.25 & 4.47 & 8.47 & 11.56 & 6.50 & 3 \\
\hline Paratype no. 6 & MLP13613 & 18.03 & 9.29 & 13.99 & 3.99 & 6.66 & 10.03 & 5.10 & 3 \\
\hline Paratype no. 7 & MLP13613 & 26.49 & 11.41 & 17.05 & 4.86 & 8.07 & 12.18 & 5.95 & 4 \\
\hline Paratype no. 8 & MLP13613 & 24.96 & 10.65 & 16.27 & 4.31 & 7.54 & 12.13 & 5.34 & 4 \\
\hline Paratype no. 9 & MLP13613 & 25.09 & 10.86 & 16.94 & 4.06 & 7.60 & 11.84 & 5.57 & 4 \\
\hline Paratype no. 10 & MLP13613 & 25.60 & 9.98 & 16.04 & 4.01 & 7.21 & 11.74 & 4.94 & 5 \\
\hline Paratype no. 11 & MLP13613 & 24.84 & 9.86 & 15.96 & 3.89 & 7.12 & 11.24 & 5.12 & 5 \\
\hline Paratype no. 12 & MLP13613 & 24.20 & 9.77 & 15.82 & 4.13 & 7.03 & 11.42 & 5.18 & 4 \\
\hline Paratype no. 13 & MLP13613 & 21.21 & 8.56 & 13.56 & 3.35 & 6.41 & 9.80 & 4.70 & 5 \\
\hline Paratype no. 14 & MLP13758 & 21.94 & 9.01 & 14.80 & 3.57 & 6.52 & 10.75 & 4.90 & 4 \\
\hline Paratype no. 15 & MLP13613 & 20.00 & 9.26 & 14.03 & 4.03 & 6.72 & 10.25 & 4.83 & 3 \\
\hline Paratype no. $16^{*}$ & MLP13613 & 13.30 & 6.06 & 8.68 & 2.45 & 4.18 & 6.13 & 3.05 & 4 \\
\hline Paratype no. $17^{*}$ & MLP13613 & 13.53 & 6.04 & 9.32 & 2.37 & 4.46 & 6.61 & 3.38 & 3 \\
\hline Paratype no. $18^{*}$ & MLP13613 & 14.74 & 7.01 & 10.08 & 2.82 & 4.90 & 7.31 & 3.60 & 3 \\
\hline
\end{tabular}

Measurements in mm.

TL, total length; TW, total width; BWL, length of body whorl; PWL, penultimate whorl length; SW, spire width; AL, aperture length; AW, aperture width; NW, number of whorls.

*juvenile specimens.

of some rows with cusps showing different levels of fusion, occasionally developing bifid or trifid points. Marginal teeth similar to one another, long, spatulate, narrow on base, with slender, fringe-like cusps. Inner marginal teeth with about eight cusps; outer marginals with about 11 thinner cusps (Fig. 10F). Rectum lacking transverse inner folds. Several faecal pellets inside rectum oblique compacted (Fig. 9B).

Circulatory and excretory systems: Heart and kidney characters and location similar to those of preceding species. 


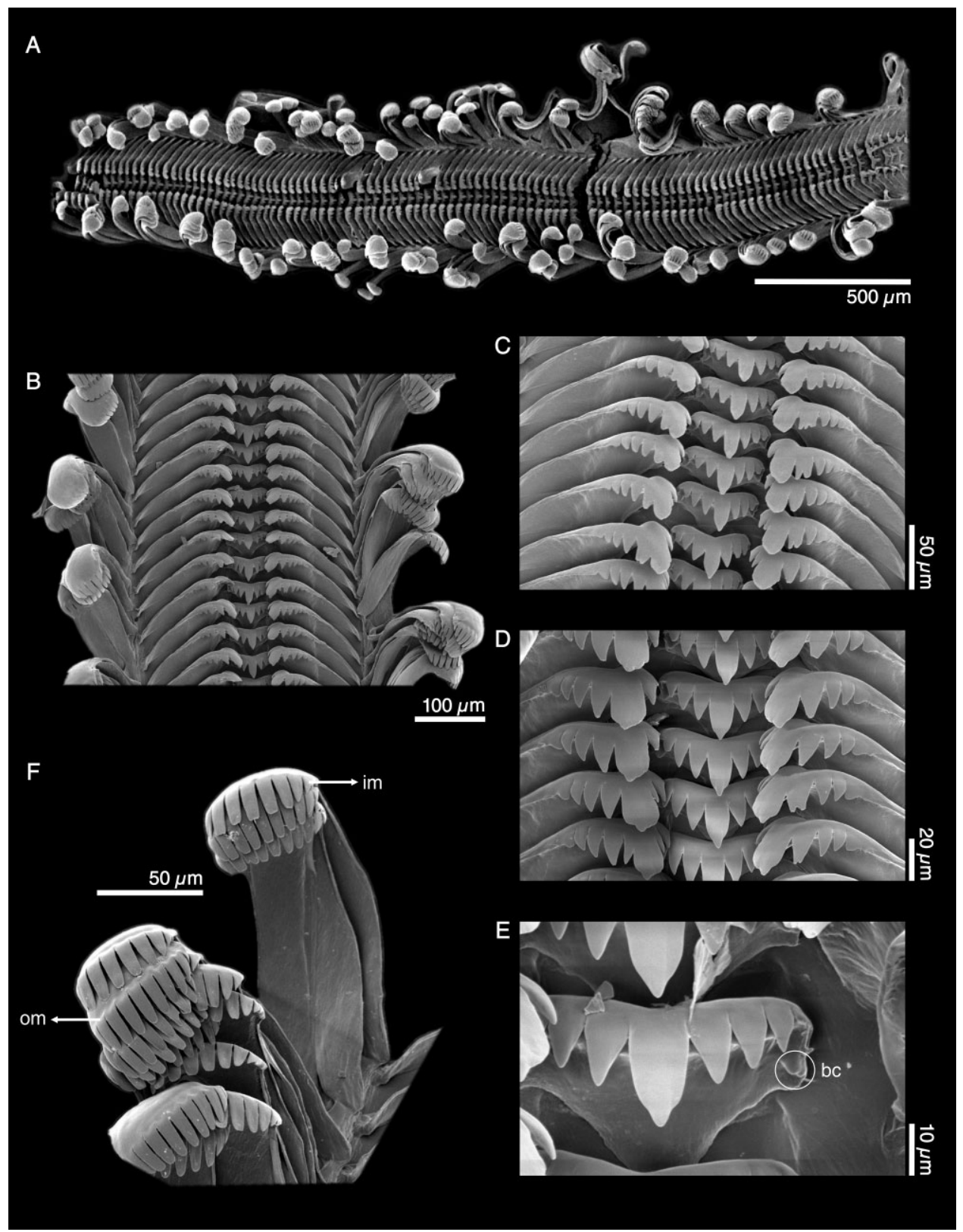

Figure 10. Scanning electron micrographs of radula of Aylacostoma brunneum sp. nov. A, radular ribbon. B, radular segment. C, D, detail showing central and lateral teeth. E, rachidian with basal cusps. F, marginal teeth. Abbreviations: bc, basal cusps; im, inner marginal; om, outer marginal.

Genital system: Similar to preceding species. Only females found, with up to four specimens within brood pouch.

\section{Distribution (Fig. 11)}

Endemic to High Paraná River at the border area between Argentina and Paraguay. This new species was recorded in 2007 from only two localities. As the main channel of the river is the boundary between the two countries, both localities territorially correspond to Para- guay: Río Beach, Itapúa, $27^{\circ} 24^{\prime} 29.83^{\prime \prime} \mathrm{S}, 55^{\circ} 49^{\prime} 32.94^{\prime \prime} \mathrm{W}$ (type locality) and Ita Cuá, Itapúa, $27^{\circ} 24^{\prime} 42.13^{\prime \prime} \mathrm{S}$, $55^{\circ} 48^{\prime} 45.69^{\prime \prime} \mathrm{W}$. In 2011 , these localities were flooded in the last filling stage of the Yacyretá Reservoir.

\section{DNA barcoding}

Partial sequences of mitochondrial $C O I$ and $C y t b$ genes of the holotype have been deposited in GenBank with accession numbers JQ236705 and KF918858, respectively. Additional partial $\mathrm{COI}$ sequences from other living 


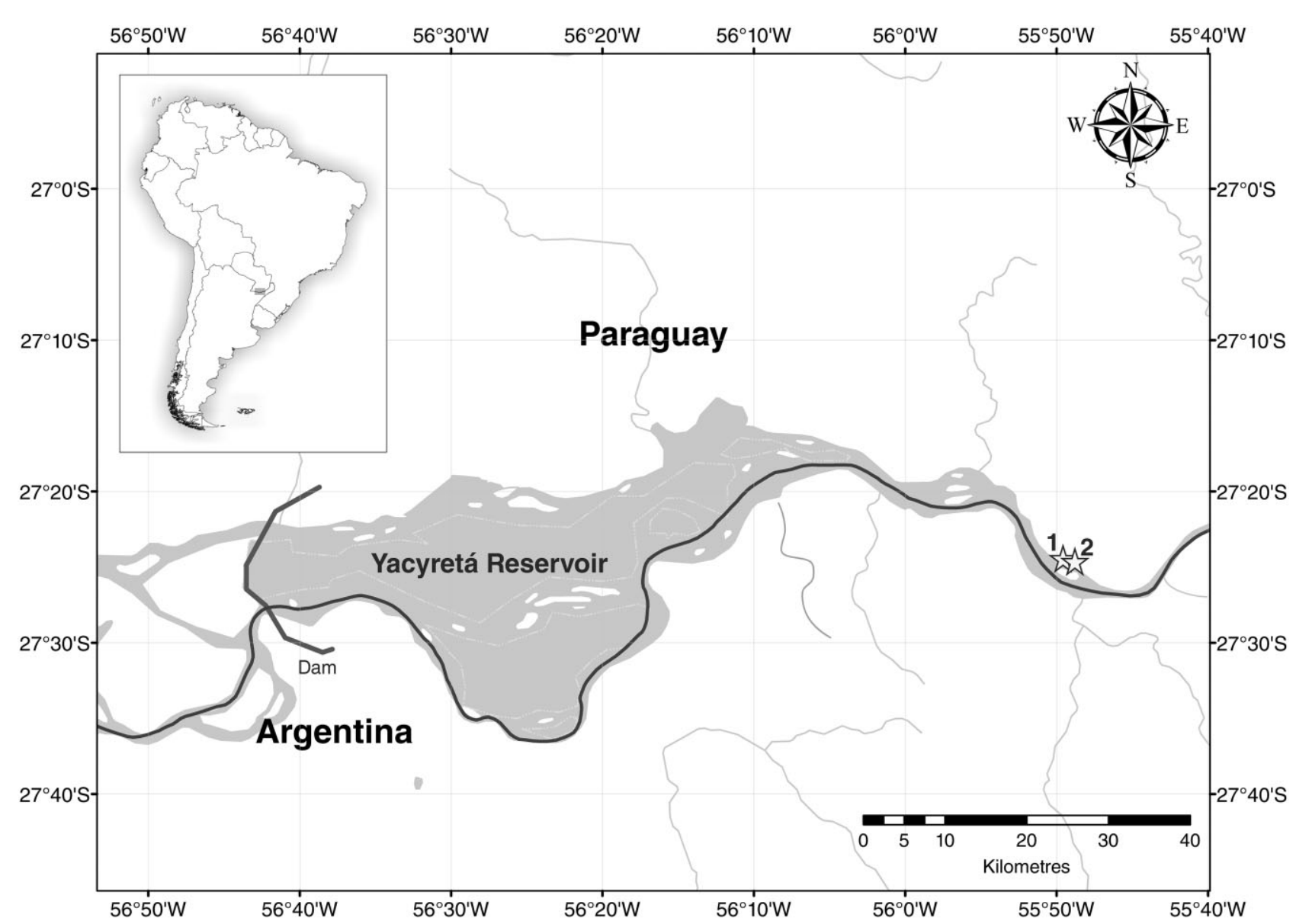

Figure 11. Known distribution of Aylacostoma brunneum sp. nov. in the High Paraná River. 1, Río Beach, Itapúa, Paraguay (type locality). 2, Ita Cuá, Itapúa, Paraguay.

specimens born in captivity at UNaM have been deposited in GenBank under accession numbers JQ236700-JQ236704.

\section{Conservation status}

Representatives of two known geographical populations are reproducing successfully in captivity within the 'Aylacostoma Project' at UNaM. The status of the species in the wild remains uncertain, but the populations are assumed to have become extinct after the completion of the filling up process of the Yacyretá Reservoir in 2011. The inclusion of A. brunneum in the IUCN and Convention on International Trade in Endangered Species of Wild Fauna and Flora lists is recommended.

\section{DISCUSSION}

Nonmarine molluscs belong to the second most diverse animal phylum in terms of number of described species (Lydeard et al., 2004). The estimated number of nonmarine molluscs comprises about 24000 terres- trial and 4000 freshwater valid described species (Lydeard et al., 2004; Strong et al., 2008). However, molluscs have the highest number of documented extinctions of any major taxonomic group (Lydeard et al., 2004; Strong et al., 2008). In particular, freshwater gastropods (approximately 5\% of the world's gastropod fauna) are at disproportionately high risk of extinction (Strong et al., 2008). Of the 310 species listed as extinct in the 2013 IUCN Red List of Threatened Species (http:// www.redlist.org), $73(\sim 23 \%)$ are gastropod species from inland waters. Moreover, when corrected for knowledge bias, the number of known extinctions is markedly increased (Régnier, Fontaine \& Bouchet, 2009).

Argentina has a total of 101 recorded species of freshwater gastropods distributed in ten families, 40 of which have been recognized as endemic and 45 considered vulnerable (Rumi et al., 2006, 2008; Núñez et al., 2010). Of the latter, conservation strategies have been adopted only for the native thiarids from the High Paraná River in the context of the 'Aylacostoma Project'. To our knowledge, this conservation breeding programme is the only one being developed for 
freshwater gastropods in South America and constitutes an example of conservation success, similar to those programmes being developed for other seriously threatened snails of the Pacific islands, such as Achatinella and Partula (Pearce-Kelly et al., 1997; Hadfield, Holland \& Olival, 2004).

Within the framework of the aforementioned project, this study has described for the first time the morphological and genetic characters of two threatened representatives of Aylacostoma from the High Paraná River, A. chloroticum and the new species $A$. brunneum. The most notable differences between them are concentrated on their shells, which are mainly distinguished by their distinctive coloration patterns. The new species also differs from A. chloroticum and the extinct $A$. guaraniticum in having a lower number of whorls. Owing to its relatively low spire and the swelling of the body whorl, $A$. brunneum resembles the extinct A. stigmaticum although it differs from it by lacking the yellow horn colour and by the absence of its typical black spots (Hylton Scott, 1954; Peso et al., 2013b).

Anatomically, the general scheme of the internal organization of the species described here fits well with that reported for A. guaraniticum by Castellanos (1981). The new species differs from A. chloroticum by the constant presence of the distinctive vessels in the area between the gills and the adrectal sinus. The lack of conspicuous vascularization in that area found in some of the specimens of $A$. chloroticum resembles the Brazilian Aylacostoma ci Simone, 2001, described and illustrated in Simone (2001). Nonetheless, both species from the High Paraná River differ from their Brazilian congeners by their shells and the presence of two basal cusps on the rachidian teeth, both of which are lacking in the three Brazilian species characterized by Simone (2001, 2011). These cusps also discriminate the species studied here from $A$. guaraniticum, for which only one basal cusp has been reported (Hylton Scott, 1953), but not from A. stigmaticum, whose radula (Vogler, 2013) is similar to those reported in this study. As noted by Vogler (2013), the basal cusps are not visible at first sight under SEM, and the presence and number of basal cusps as a useful character for differentiating species, at least amongst those from ArgentinaParaguay and Brazil, needs to be confirmed by more evidence from further species.

Although it was possible to discriminate the two species from High Paraná River studied here from those for which anatomical data are available, remarkably no major differences were found to allow an accurate diagnosis based on anatomical characters alone, at least at the level of detail of this study. Some evidence for this situation can be found in the recent study of comparative anatomy published by Simone (2011), where 305 species of Caenogastropoda were analysed by means of 676 morphological characters with 2291 states, in- cluding three Aylacostoma representatives from Brazil, A. ci, Aylacostoma exoplicata Simone, 2001, and Aylacostoma tenuilabris (Reeve, 1860). Despite the goal of Simone's study being to reconstruct higher-order relationships, by analysing the characters matrix presented, we found that only six of the 676 characters were coded with different states for the Brazilian species (Simone, 2011).

In order to make sound decisions regarding the specific status of members of the genus Aylacostoma, we suggest that an integrative vision is necessary, complementing the conchological and anatomical data with evidence from other approaches. In this sense, ecology and life history data could be helpful for this decision process; however, as noted in the Introduction, this information is still scarce and constitutes a generalization for all the species currently included in Aylacostoma. The molecular data presented here, the first for any species of the genus according to our knowledge, have shown that the mitochondrial regions employed constitute useful markers for discriminating between the species. Taking into account that $A$. chloroticum and A. brunneum are considered to be fully asexually reproducing taxa, they seem to be highly divergent in terms of genetic distance (as evidenced by values of c. 4.26 and $4.41 \%$ for $C O I$ and $6.65 \%$ for $C y t$ b), especially when compared with the smaller interspecific distances of other endemic freshwater gastropods (e.g. Hershler, Liu \& Thompson, 2003; Köhler, Panha \& Glaubrecht, 2010). With these percentages in hand, and in view of the fact that they are reciprocally monophyletic, the High Paraná representatives could be delineated as species by applying the $10 \%$ sequence divergence rule (10X rule) proposed by Hebert et al. (2004) as their divergence clearly exceeds this recommended threshold. However, the use of divergence thresholds has been strongly discouraged (Frézal \& Leblois, 2008). On the contrary, the EGSC has been proposed and applied to delineate parthenogenetic species of mites, rotifers, and ostracods (Birky \& Barraclough, 2009; Birky et al., 2010, 2011; Martens et al., 2012; Shearn et al., 2012). This concept is based on evolutionary and population genetics, as well as data from DNA sequences, and has been developed with special emphasis on the speciation of asexual organisms (Birky et al., 2005, 2010; Birky \& Barraclough, 2009).

By using the $K / \theta$ method with our $C O I$ data, we have clearly recognized $A$. chloroticum and $A$. brunneum as distinct evolutionary genetic species, despite the lack of major distinguishable morphological features other than shells. Thus, we suggest that the EGSC could be a useful framework with which to comprehensively review the specific status of the gastropods of this genus. This would probably open the way to a greater understanding of the species included in Aylacostoma and their evolutionary relationships. 


\section{ACKNOWLEDGEMENTS}

We thank the Agencia Nacional de Promoción Científica y Tecnológica (ANPCyT; BID-PICT-2008-2042) and Conservation, Research and Education Opportunities International (CREOI) for funding this study. We are especially grateful to Dr C. William Birky Jr (University of Arizona) for assisting us in the implementation of the $K / \theta$ method, and to three anonymous reviewers for providing helpful comments on the manuscript.

\section{REFERENCES}

Altschul SF, Gish W, Miller W, Myers EW, Lipman DJ. 1990. Basic local alignment search tool. Journal of Molecular Biology 215: 403-410.

Birky CW Jr. 2013. Species detection and identification in sexual organisms using population genetic theory and DNA sequences. PLoS ONE 8: e52544. doi: 10.1371/journal.pone. 0052544.

Birky CW Jr, Adams J, Gemmel M, Perry J. 2010. Using population genetic theory and DNA sequences for species detection and identification in asexual organisms. PLoS ONE 5: e10609. doi:10.1371/journal.pone.0010609.

Birky CW Jr, Barraclough TG. 2009. Asexual species. In: Schön I, Martens K, van Dijk P, eds. Lost sex - The evolutionary biology of parthenogenesis. New York: Springer Publications, 201-216.

Birky CW Jr, Ricci C, Melone G, Fontaneto D. 2011. Integrating DNA and morphological taxonomy to describe diversity in poorly studied microscopic animals: new species of the genus Abrochtha Bryce, 1910 (Rotifera: Bdelloidea: Philodinavidae). Zoological Journal of the Linnean Society 161: 723-734.

Birky CW Jr, Wolf C, Maughan H, Herbertson L, Henry E. 2005. Speciation and selection without sex. Hydrobiologia 546: $29-45$.

de Castellanos ZJA. 1981. La familia Thiaridae Morrison 1952 en la Argentina. In: Ringuelet RA, ed. Fauna de agua dulce de la República Argentina. Buenos Aires: Fundación para la Educación, la Ciencia y la Cultura, 7-18.

de Castellanos ZJA, Landoni NA. 1995. Mollusca Pelecypoda y Gastropoda. In: Lopretto EC, Tell G, eds. Ecosistemas de aguas continentales. Metodologías para su estudio Vol. 2. La Plata: Ediciones Sur, 759-801.

Cazzaniga NJ. 1992. Dr. María Isabel Hylton Scott (18891990). A brief biography and bibliography. Walkerana 6: 295313.

Cazzaniga NJ. 2011. El género de los géneros. Una guía para formar y coordinar nombres científicos en zoología. Bahía Blanca: EdiUNS.

Felsenstein J. 1985. Confidence limits on phylogenies: an approach using the bootstrap. Evolution 39: 783-791.

Folmer O, Black M, Hoeh W, Lutz R, Vrijenhoek R. 1994. DNA primers for amplification of mitochondrial cytochrome c oxidase subunit I from diverse metazoan invertebrates. Molecular Marine Biology and Biotechnology 3: 294-299.

Frézal L, Leblois R. 2008. Four years of DNA barcoding: current advances and prospects. Infection, Genetics and Evolution 8: 727-736.

Glaubrecht M. 1996. Evolutionsökologie und Systematik am Beispiel von Sü $\beta$ - und Brackwasserschnecken (Mollusca: Caenogastropoda: Cerithioidea): Ontogenese-Strategien, paläontologische Befunde und Historische Zoogeographie. Leiden: Backhuys Publishers.

Glaubrecht M. 1999. Systematics and the evolution of viviparity in tropical freshwater gastropods (Cerithioidea: Thiaridae sensu lato) - an overview. Courier Forschungsinstitut Senckenberg 215: 91-96.

Glaubrecht M. 2006. Independent evolution of reproductive modes in viviparous freshwater Cerithioidea (Gastropoda, Sorbeoconcha): a brief review. Basteria 69 (Suppl. 3): 28-32.

Gomez MI, Strong EE, Glaubrecht M. 2011. Redescription and anatomy of the viviparous freshwater gastropod Hemisinus lineolatus (W. Wood, 1828) from Jamaica (Cerithioidea, Thiaridae). Malacologia 53: 229-250.

Gutiérrez Gregoric DE, Beltramino AA, Vogler RE, Cuezzo MG, Núñez V, Gomes SR, Virgillito M, Miquel SE. 2013. First records of four exotic slugs in Argentina. American Malacological Bulletin 31: 245-256.

Gutiérrez Gregoric DE, Núñez V, Ferrando NS, Rumi A. 2007. First record of invasive snail Melanoides tuberculatus (Müller) (Gastropoda: Prosobranchia: Thiaridae) for the Iguazú River Basin, Argentina - Brazil. Comunicaciones de la Sociedad Malacológica del Uruguay 9: 109-112.

Gutiérrez Gregoric DE, Núñez V, Rumi A, Roche MA. 2006. Freshwater gastropods from Del Plata Basin, Argentina. Checklist and new locality records. Comunicaciones de la Sociedad Malacológica del Uruguay 9: 51-60.

Hadfield MG, Holland BS, Olival KJ. 2004. Contributions of ex situ propagation and molecular genetics to conservation of Hawaiian tree snails. In: Gordon MS, Bartol SM, eds. Experimental approaches to conservation biology. Berkeley: University of California Press, 16-34.

Hebert PDN, Stoeckle MY, Zemlak TS, Francis CM. 2004. Identification of birds through DNA barcodes. PLoS Biology 2: e312. doi:10.1371/journal.pbio.0020312.

Hershler R, Liu HP, Thompson FG. 2003. Phylogenetic relationships of North American nymphophiline gastropods based on mitochondrial DNA sequences. Zoologica Scripta 32: 357-366.

Holznagel W. 1998. A nondestructive method for cleaning gastropod radulae from frozen, alcohol-fixed, or dried material. American Malacological Bulletin 14: 181-183.

Hylton Scott MI. 1953. El género Hemisinus (Melaniidae) en la costa fluvial Argentina (Mol. Prosobr.). Physis 20: 438443.

Hylton Scott MI. 1954. Dos nuevos melánidos del Alto Paraná (Mol. Prosobr.). Neotropica 1: 45-48.

Ihering H. 1902. As melanias do Brazil. Revista do Museu Paulista 5: 653-682.

Ihering H. 1909. Les mélaniidés américains. Journal de Conchyliologie 57: 289-316. 
Köhler F, Panha S, Glaubrecht M. 2010. Speciation and radiation in a river: assessing the morphological and genetic differentiation in a species Flock of viviparous gastropods (Cerithioidea: Pachychilidae). In: Glaubrecht M, ed. Evolution in action. Heidelberg: Springer-Verlag, 513-550.

Larkin MA, Blackshields G, Brown NP, Chenna R, McGettigan PA, McWilliam H, Valentin F, Wallace IM, Wilm A, Lopez R, Thompson JD, Gibson TJ, Higgins DG. 2007. Clustal W and Clustal $X$ version 2.0. Bioinformatics 23: 2947-2948.

Lydeard C, Cowie RH, Ponder WF, Bogan AE, Bouchet P, Clark SA, Cummings KS, Frest TJ, Gargominy O, Herbert DG, Hershler R, Perez KE, Roth B, Seddon M, Strong EE, Thompson FG. 2004. The global decline of nonmarine mollusks. BioScience 54: 321-330.

Mansur MCD. 2000a. Aylacostoma guaraniticum. In: IUCN 2013. IUCN Red List of Threatened Species. Version 2013.1. Available at: http://www.iucnredlist.org (accessed November 2013).

Mansur MCD. 2000b. Aylacostoma stigmaticum. In: IUCN 2013. IUCN Red List of Threatened Species. Version 2013.1. Available at: http://www.iucnredlist.org (accessed November 2013).

Mansur MCD. 2000c. Aylacostoma chloroticum. In: IUCN 2013. IUCN Red List of Threatened Species. Version 2013.1. Available at: http://www.iucnredlist.org (accessed November 2013).

Martens K, Halse S, Schön I. 2012. Nine new species of Bennelongia De Deckker \& McKenzie, 1981 (Crustacea, Ostracoda) from Western Australia, with the description of a new subfamily. European Journal of Taxonomy 8: 1-56.

Martín SM, César II. 2004. Catálogo de los tipos de moluscos (Gastropoda, Bivalvia, Cephalopoda) del Museo de La Plata. La Plata: Fundación Museo de La Plata.

Meichtry de Zaburlín NR, Peso JG, Garrido G, Vogler RE. 2010. Sucesión espacio-temporal del plancton y bentos en periodos posteriores al llenado del Embalse Yacyretá (Río Paraná, Argentina-Paraguay). Interciencia 35: 897-904.

Merritt TJS, Shi L, Chase MC, Rex MA, Etter RJ, Quattro JM. 1998. Universal cytochrome $b$ primers facilitate intraspecific studies in molluscan taxa. Molecular Marine Biology and Biotechnology 7: 7-11.

Morrison JPE. 1954. The relationship of old and new world melanians. Proceedings of the United States National Museum 103: $357-394$.

Núñez V, Gutiérrez Gregoric DE, Rumi A. 2010. Freshwater gastropod provinces from Argentina. Malacologia 53: $47-60$.

Ostrowski de Núñez M, Quintana MG. 2008. The life cycle of Stephanoprora aylacostoma n.sp. (Digenea: Echinostomatidae), parasite of the threatened snail Aylacostoma chloroticum (Prosobranchia, Thiaridae), in Argentina. Parasitology Research 102: 647-655.

Pearce-Kelly P, Clarke D, Walker C, Atkin P. 1997. A conservation programme for the partulid tree snails of the Pacific region. Memoirs of the Museum of Victoria 56: 431-433.

Peso JG, Costigliolo Rojas C, Molina MJ. 2013b. Aylacostoma stigmaticum Hylton Scott, 1954: antecedentes de la especie. Amici Molluscarum 21: 43-46.
Peso JG, Molina MJ, Costigliolo Rojas C. 2013a. Aylacostoma guaraniticum (Hylton Scott, 1953): antecedentes de la especie. Amici Molluscarum 21: 39-42.

Quintana MG. 1982. Catálogo preliminar de la malacofauna del Paraguay. Revista del Museo Argentino de Ciencias Naturales Bernardino Rivadavia 11: 61-158.

Quintana MG, Mercado Laczkó AC. 1997. Caracoles de los rápidos en Yacyretá. Ciencia Hoy 7: 22-31.

Quintana MG, Peso JG, Pérez DC. 2001. Alteración del régimen fluvial y reemplazo de especies de Thiaridae en el embalse de Yacyretá (Argentina-Paraguay). Journal of Medical and Applied Malacology 11: 107-112.

Reeve LA. 1860. Monograph of the genus Hemisinus. Conchologia Iconica 12: 6 pls.

Régnier C, Fontaine B, Bouchet P. 2009. Not knowing, not recording, not listing: numerous unnoticed mollusk extinctions. Conservation Biology 23: 1214-1221.

Ronquist F, Teslenko M, van der Mark P, Ayres DL, Darling A, Höhna S, Larget B, Liu L, Suchard MA, Huelsenbeck JP. 2012. MrBayes 3.2: efficient bayesian phylogenetic inference and model choice across a large model space. Systematic Biology 61: 539-542.

Rumi A, Gutiérrez Gregoric DE, Núñez V, Darrigran GA. 2008. Malacología Latinoamericana. Moluscos de agua dulce de Argentina. Revista de Biología Tropical 56: 77111.

Rumi A, Gutiérrez Gregoric DE, Núñez V, César II, Roche MA, Tassara MP, Martín SM, López Armengol F. 2006. Freshwater Gastropoda from Argentina: species richness, distribution patterns, and an evaluation of endangered species. Malacologia 49: 189-208.

Rumi A, Gutiérrez Gregoric DE, Núñez V, Tassara MP, Martín SM, López Armengol MF, Roche A. 2004. Biodiversidad de moluscos de agua dulce de la Región Mesopotámica, Argentina. Instituto Superior de Correlación Geológica, Miscelánea 12: 211-216.

Schön I, Pinto RL, Halse S, Smith AJ, Martens K, Birky CW Jr. 2012. Cryptic species in putative ancient asexual Darwinulids (Crustacea, Ostracoda). PLoS ONE 7: e39844. doi:10.1371/journal.pone.0039844.

Shearn R, Koenders A, Halse S, Schön I, Martens K. 2012. A review of Bennelongia De Deckker \& McKenzie, 1981 (Crustacea, Ostracoda) species from eastern Australia with the description of three new species. European Journal of Taxonomy 25: 1-35.

Simone LRL. 2001. Phylogenetic analysis of Cerithioidea (Mollusca: Caenogastropoda) based on comparative morphology. Arquivos de Zoologia 36: 147-263.

Simone LRL. 2006. Land and freshwater molluscs of Brazil. São Paulo: EGB, Fapesp.

Simone LRL. 2011. Phylogeny of the Caenogastropoda (Mollusca), based on comparative morphology. Arquivos de Zoologia 42: 161-323.

Strong EE, Colgan DJ, Healy JM, Lydeard C, Ponder WF, Glaubrecht M. 2011. Phylogeny of the gastropod superfamily Cerithioidea using morphology and molecules. Zoological Journal of the Linnean Society 162: 4389. 
Strong EE, Gargominy O, Ponder WF, Bouchet P. 2008. Global diversity of gastropods (Gastropoda; Mollusca) in freshwater. Hydrobiologia 595: 149-166.

Tablado A, Mantinian J. 2004. Catálogo de ejemplares tipo de la División Invertebrados del Museo Argentino de Ciencias Naturales. II. Mollusca. Revista del Museo Argentino de Ciencias Naturales, Nueva Serie 6: 363-384.

Tamura K, Nei M, Kumar S. 2004. Prospects for inferring very large phylogenies by using the neighbor-joining method. Proceedings of the National Academy of Sciences, USA 101: 11030-11035.

Tamura K, Peterson D, Peterson N, Stecher G, Nei M, Kumar S. 2011. MEGA5: molecular evolutionary genetics analysis using maximum likelihood, evolutionary distance, and maximum parsimony methods. Molecular Biology and Evolution 28: 2731-2739.

Vogler RE. 2012. Aylacostoma chloroticum Hylton Scott, 1954: antecedentes de la especie. Amici Molluscarum 20: 43-46.

Vogler RE. 2013. The radula of the extinct freshwater snail Aylacostoma stigmaticum (Caenogastropoda: Thiaridae) from Argentina and Paraguay. Malacologia 56: 329-332.

Vogler RE, Beltramino AA, Gutiérrez Gregoric DE, Peso JG, Griffin M, Rumi A. 2012. Threatened Neotropical mollusks: analysis of shape differences in three endemic snails from High Paraná River by geometric morphometrics. Revista Mexicana de Biodiversidad 83: 1045-1052. 